\title{
Comparative Aquatic Toxicity of Gold Nanoparticles and Ionic Gold Using a Species Sensitivity Distribution Approach
}

\author{
Tarryn L. Botha, ${ }^{1}$ Tanyn E. James, ${ }^{1}$ and Victor Wepener ${ }^{2}$ \\ ${ }^{1}$ Department of Zoology, University of Johannesburg, P.O. Box 534, Auckland Park 2006, South Africa \\ ${ }^{2}$ Unit for Environmental Sciences and Management, Water Research Group (Ecotoxicology), North-West University, \\ Private Bag X6001, Potchefstroom 2520, South Africa \\ Correspondence should be addressed to Tarryn L. Botha; tlbothanano@gmail.com
}

Received 22 May 2015; Accepted 23 June 2015

Academic Editor: Kangtaek Lee

Copyright (c) 2015 Tarryn L. Botha et al. This is an open access article distributed under the Creative Commons Attribution License, which permits unrestricted use, distribution, and reproduction in any medium, provided the original work is properly cited.

\begin{abstract}
Gold nanoparticles $(\mathrm{nAu})$ are used in drug delivery systems allowing for targeted cellular distribution. The effects of increased use and release of nanoparticles into the environment are not well known. A species sensitivity distribution (SSD) allows for the ecotoxicological hazard assessment of a chemical based on single species toxicity tests. Aquatic toxicity needs to be related to particle characterization in order to understand the effects. The behaviour of nAu in the medium changed as the concentration increased. The toxic potential of ionic gold and nAu was expressed as a hazardous concentration where $5 \%$ of species will be harmed (HC5). The HC5 for nAu was much higher $(42.78 \mathrm{mg} / \mathrm{L})$ compared to the ionic gold $(2.44 \mathrm{mg} / \mathrm{L})$. The differences between the hazard potentials of $\mathrm{nAu}$ and ionic gold were attributed to the nAu not releasing any Au ions into solution during the exposures and following an aggregation theory response. Exposures to ionic gold on the other hand followed a clear dose dependent response based on the concentration of the ionic metal. Although SSDs present an indication of the relative hazard potential of nanoparticles, the true worth can only be achieved once other nanoparticle characteristics and their behavior in the environment are also considered.
\end{abstract}

\section{Introduction}

In recent years, gold nanoparticles $(\mathrm{nAu})$ have been studied and developed within the biological and photothermal therapeutic contexts. The major clinical interest is within the application of novel drug delivery systems and targeted delivery into cells $[1-4]$ as well as microelectromechanical systems [5] and diagnostic systems [6]. Exposure of nanoparticles can occur in different stages of the lifecycle of the product, from their synthesis, application (which can include ingestion or intravenously), and weathering to their waste disposal. Due to little research within this field there are currently no guidelines for their use; therefore, the previously mentioned exposure routes could build up in the environment $[1,7-10]$.

To manage environmental resources such as water quality, laboratory toxicity tests are used worldwide and are deemed as the first step in a tiered approach to set up guidelines for acceptable maximum concentrations of specific pollutants [11-14]. Bioassays are employed to find toxicity which could come from complex mixtures and are a complementary tool to assess toxic effects overcoming certain limitations and are relatively rapid, cost effective, and simple to perform [15-17]. Bioassays can detect synergistic, antagonistic, and additive effects and also explain both point and diffuse sources of aquatic pollution since they are site specific $[15,18-$ 20]. Several different bioassays are used simultaneously at different trophic levels of different biological complexity to sufficiently assess whether a potential hazard exists [11, 21] since no single test is suitable to measure all ecological risks due to different sensitivities by organisms [17, 22-24].

Species sensitivity distributions (SSDs) are being integrated into ecological risk assessments to evaluate the toxicity of particular chemicals [25]. An SSD is a distribution of statistical data approximated from a set of toxicity data and observed as a function of accumulative distribution [26, 27]. Species sensitivity distributions are used to calculate the concentration at which a specified proportion of species will be affected. The SSD provides a plot of logarithmic toxicity endpoints, specifically LC50 (the lethal concentration of toxicant that causes $50 \%$ death of test organisms at a specific 
period of time) against rank-assigned percentiles for each endpoint value to which a statistical distribution is fitted [28]. A resulting hazard concentration $(\mathrm{HC} p)$ is produced from the SSD which is expressed as the percentage $(p)$ of all species that are presumed to become affected $[28,29]$. Toxicological databases are key factors in the derivation of water quality guidelines; thus SSDs are more commonly used in ecological risk assessments and generating water quality guidelines $[28,30]$. The application of SSDs to evaluate the hazard of nanoparticles is fairly new since the database for nanoparticle toxicity data is relatively small compared to bulk chemical equivalents. Adam et al. [31] and Garner et al. [32] made use of SSDs to compare the relative toxicity of nanoparticles for which data are available, for example, $\mathrm{CuO}, \mathrm{ZnO}, \mathrm{TiO}_{2}$, and carbon nanotubes. Many nanoparticle ecotoxicity studies highlight the importance of physicochemical nanoparticle characterization in the exposure media to be able to link exposure to effect $[11,33-35]$. However there are very limited data for $\mathrm{nAu}$. Therefore the aim of this study was to determine the comparative toxicity of aquatic organisms exposed to $\mathrm{nAu}$ and ionic gold using an SSD approach. The study also aimed to link mortality to the nAu particle characteristics.

\section{Materials and Methods}

2.1. Gold Nanoparticle and Ionic Gold Stock Solutions. The nAu stock solution $(14 \pm 2 \mathrm{~nm} \mathrm{nAu}$ with product code TMU14G, batch numbers 20130304FKP49b, 20130308FKP52, and 20140905BM001) was prepared by standard citrate reduction techniques according to Murphy et al. [36] and Fren [37] and was sterilized using the filtration method. Gold used for ionic exposures was purchased in powder form from Aldrich (USA) as gold(III) chloride and was dissolved in standard OECD medium to a stock solution concentration of $1 \mathrm{~g} / \mathrm{L}$ of $\mathrm{Au}^{3+}$ prior to the preparation of exposure concentrations.

2.2. Preparation of Environmental Media as Diluent for $n A u$ Suspensions of Varying Concentrations. The reconstituted water for Daphnia toxicity testing was performed by making a standard OECD [38] medium $\left(\mathrm{NaHCO}_{3}, \mathrm{CaSO}_{4} \cdot 2 \mathrm{H}_{2} \mathrm{O}, \mathrm{KCl}\right.$, and $\mathrm{MgSO}_{4} \cdot 7 \mathrm{H}_{2} \mathrm{O}$ ). The standard OECD medium [38] for fish toxicity testing contained $\mathrm{CaCl}_{2} \cdot 2 \mathrm{H}_{2} \mathrm{O}, \mathrm{MgSO}_{4} \cdot 7 \mathrm{H}_{2} \mathrm{O}$, $\mathrm{NaHCO}_{3}$, and $\mathrm{KCl}$. The reconstituted water media were aerated for 24 hours prior to use [39]. The nAu stock solution was placed in an ultrasonicator bath and sonicated for two hours prior to use. To make up the required exposure concentrations, relevant volumes of the nAu stock were added to the environmental media water.

2.3. Physicochemical Water Quality. Physicochemical water quality parameters were measured according to standard test protocols [36]. Measurements were taken at the start of the test and at 24-hour (h) intervals until the tests were concluded. The $\mathrm{pH}$, electrical conductivity (EC), total dissolved solids (TDS), oxygen saturation $\left(\% \mathrm{O}_{2}\right)$, and dissolved oxygen $(\mathrm{DO})$ concentration $(\mathrm{mg} / \mathrm{L})$ were measured using a handheld Eutech pH 110 RS232C meter, Eutech CON 110 RS232C conductivity and TDS meter, and Eutech DO6 DO meter. The oxygen saturation was maintained above $60 \%$ for the duration of the test by bubbling compressed air into the exposure beakers.

2.4. Nanoparticle Exposure Concentration. Total gold concentrations were determined at the start of the toxicity bioassay $(0 \mathrm{~h})$ as well as at the conclusion of the assay $(48 \mathrm{~h}$ or $96 \mathrm{~h}$ where relevant) to verify nominal concentrations in both ionic and $\mathrm{nAu}$ exposures. Samples $(11 \mathrm{~mL})$ were acidified with $3 \mathrm{~mL}$ Suprapur 30\% hydrochloric acid (Merck) and $1 \mathrm{~mL} 65 \% \mathrm{HNO}_{3}$ to ensure that all of the gold was in ionic form. Inductively coupled plasma atom emission spectroscopy (ICP-OES) (Spectro Arcos FSH12) techniques were used to analyse the water samples.

2.5. Characterization of $n A u$ Particles. Based on the recommendations by von der Kammer et al. [42], Stone et al. [43], and Klaine et al. [35], the following characteristics were determined: concentration, size distribution, surface charge, surface functionality, and agglomeration patterns. Dynamic light scattering (Malvern Zetasizer Nano series, NanoZS) was used to measure the hydrodynamic size distribution and zeta potential of the $\mathrm{nAu}$ in solution. Fourier transform infrared spectrometry (FTIR) (Perkin Elmer FTIRspectrometer, Spectrum 100) was used to determine the $\mathrm{nAu}$ surface functionality and provide insight into possible reasons of particle aggregation. These measurements were taken at $0 \mathrm{~h}$ as well as at the conclusion of the test; that is, for fish this was after $96 \mathrm{~h}$ while for Daphnia this was 48 hours. Transmission electron microscopy (TEM) (FEI Tecnai G2) was used to quantify nAu diameter and nAu surface morphology as well as show particle aggregation patterns. One drop of nAu medium was dropped onto a carbon coated copper grid and allowed to settle for a few minutes. The excess water was removed using a filter paper by touching only the edge of the droplet and the grid was allowed to dry before examination at high resolution $(200 \mathrm{kV})$.

2.6. Daphnia pulex and Daphnia magna 48-Hour Acute Immobilisation Test. The arthropods Daphnia pulex and D. magna were used for acute testing. Adults were kept in $2.5 \mathrm{~L}$ tanks in Daphnia media which were replaced three times per week and kept at a temperature of $20^{\circ} \mathrm{C}$. Five milliliters of Daphnia food was suspended in the Daphnia media at each water cycle change. Prior to testing approximately thirty adults were transferred to a new tank and neonates less than $24 \mathrm{hrs}$ old were used for the test.

For $\mathrm{nAu}$ a concentration range of $0.5 \mathrm{mg} / \mathrm{L}, 2 \mathrm{mg} / \mathrm{L}$, $5 \mathrm{mg} / \mathrm{L}, 10 \mathrm{mg} / \mathrm{L}, 15 \mathrm{mg} / \mathrm{L}, 20 \mathrm{mg} / \mathrm{L}, 25 \mathrm{mg} / \mathrm{L}, 35 \mathrm{mg} / \mathrm{L}$, and $45 \mathrm{mg} / \mathrm{L}$ was used. A separate dispersant control (the citrate buffer in which the nAu particles were dispersed) was made up in the same concentration range as the $\mathrm{nAu}$. The ionic gold exposure concentration range was $0.0005 \mathrm{mg} / \mathrm{L}, 0.005 \mathrm{mg} / \mathrm{L}$, $0.5 \mathrm{mg} / \mathrm{L}, 1 \mathrm{mg} / \mathrm{L}, 2 \mathrm{mg} / \mathrm{L}$, and $5 \mathrm{mg} / \mathrm{L}$. A positive control consisting of $1 \mathrm{~g} / \mathrm{L}$ potassium dichromate solution was also conducted. The test organisms were not fed during the assay.

Twenty-one neonates were used for each concentration and tests were carried out in triplicate with each of the three 
$50 \mathrm{~mL}$ beakers per concentration containing seven organisms. A $16 \mathrm{~h}$ light and $8 \mathrm{~h}$ dark cycle was applied for the duration of the test and the temperature was maintained at $20 \pm 2^{\circ} \mathrm{C}$. After each $24 \mathrm{~h}$ exposure period, the number of immobilized Daphnia, that is, any animal that was immobilized for more than 15 seconds, was counted. Any abnormal behaviour was also noted. The test was concluded after $48 \mathrm{~h}$.

2.7. Fish 96-Hour Acute Lethality Test. Acute toxicity tests were conducted using two standard toxicity test fish species, that is, Danio rerio (zebrafish) and Poecilia reticulata (guppy), and four indigenous fish species, that is, Labeobarbus aeneus (smallmouth yellowfish), Pseudocrenilabrus philander (southern mouthbrooder), Tilapia sparrmanii (banded tilapia), and Oreochromis mossambicus (Mozambique tilapia). All fish were maintained and cultured in the research laboratories of the University of Johannesburg. The fish acute lethality test [36] was performed on 14-day-old juveniles. Similar to the Daphnia exposures a concentration range of $5 \mathrm{mg} / \mathrm{L}, 10 \mathrm{mg} / \mathrm{L}, 15 \mathrm{mg} / \mathrm{L}, 20 \mathrm{mg} / \mathrm{L}, 25 \mathrm{mg} / \mathrm{L}, 30 \mathrm{mg} / \mathrm{L}$, $35 \mathrm{mg} / \mathrm{L}, 40 \mathrm{mg} / \mathrm{L}, 45 \mathrm{mg} / \mathrm{L}, 50 \mathrm{mg} / \mathrm{L}, 100 \mathrm{mg} / \mathrm{L}$, and $200 \mathrm{mg} / \mathrm{L}$ was used for $\mathrm{nAu}$. A range of $50 \mathrm{mg} / \mathrm{L}, 100 \mathrm{mg} / \mathrm{L}$, and $200 \mathrm{mg} / \mathrm{L}$ was used to conduct a solvent (dispersant) control assay on the citric buffer dispersant. A concentration range of $1 \mathrm{mg} / \mathrm{L}, 2 \mathrm{mg} / \mathrm{L}, 5 \mathrm{mg} / \mathrm{L}$, and $10 \mathrm{mg} / \mathrm{L}$ was used for the ionic gold (in the form of chloroauric acid) bioassay. Potassium dichromate $(1 \mathrm{~g} / \mathrm{L})$ was used as a positive control. Three replicates of seven fish per concentration were conducted in $500 \mathrm{~mL}$ beakers containing exposure medium. A $16 \mathrm{~h}$ light and $8 \mathrm{~h}$ dark cycle was maintained for the duration of the test and the temperature was maintained between $21^{\circ} \mathrm{C}$ and $25^{\circ} \mathrm{C}$. The physicochemical water quality parameters were taken at the start of the test and again at $24 \mathrm{~h}$ intervals until the test was concluded after $96 \mathrm{~h}$. The oxygen saturation was maintained above $60 \%$ for the duration of the test. If more than $10 \%$ of the juveniles died in the control the test was discarded and repeated. At $24 \mathrm{~h}$ intervals mortalities were recorded. Mortality was regarded if no visible movement was seen including gill movement. All dead fish were removed from the exposure beaker.

\subsection{Statistical Analysis}

2.8.1. Acute Toxicity. Data from the acute bioassays were analysed to calculate LC50/EC50 values using the Probit or Trimmed Spearman-Kärber methods where appropriate [44]. To determine whether there were any significant differences between the LC50 values for the different species, the following formula was used [45]: $f_{1.2}=\operatorname{antilog} \sqrt{ }\left(\left(\log f_{1}\right)^{2}+\right.$ $\left(\log f_{2}\right)^{2}$ ), where $f$ is the factor for $95 \%$ confidence limits of the LC50 and is calculated by dividing the upper confidence limit by the LC50. If the ratio of the higher LC50 to the lower LC50 exceeds the value for $f_{1.2}$ for both the upper and lower $95 \%$ confidence limits the LC50s are considered to be significantly different. The nominal concentrations were used to determine the LC50 values. In the absence of chronic data, the lowest observed effect concentration (LOEC) and no observed effect concentration (NOEC) can be useful in deriving water quality criteria. The NOEC was taken as the maximum concentration of the test materials that produced no significant harmful effect on the test organisms. The LOEC was determined as the lowest concentration that has a significant harmful effect on test organisms.

2.8.2. Species Sensitivity Distributions. The results obtained from the bioassays were used to compare the tolerances of standard test species and indigenous arthropod and fish species using an SSD approach [27]. The SSDs were produced using the CADDIS_SSD Generator [44]. Separate distribution models were constructed with the acute toxicity data collected for a range of species for $\mathrm{nAu}$ and ionic gold from which the average hazard concentration ( $\mathrm{HC} p$ ) endpoint was extrapolated. The HC5 (hazard concentration where 5\% of species are affected) was determined for freshwater fish and arthropods with exposure durations from 48 to $96 \mathrm{hrs}$. The comparisons in sensitivity were drawn between toxic responses of indigenous organisms and the standard test organisms. The taxonomic groups were analysed separately for the SSD model to illustrate the difference in tolerance between the taxa. A cumulative SSD model of all data for fish and arthropod's endpoints was also constructed for both nAu and ionic gold to ascertain the hazard threshold values.

\section{Results}

3.1. Physicochemical Water Parameters. The physicochemical water parameters were maintained within the OECD guidelines [38] as shown in Table 1. The temperature ranged between 20 and $23.9^{\circ} \mathrm{C}$ across all exposures; the $\mathrm{pH}$ was maintained between 7 and 8 but had a minimum of 6.24 and a maximum of 8.95 for chloroauric acid exposures. The DO concentration ranged between $4.44 \mathrm{mg} / \mathrm{L}$ and $9.78 \mathrm{mg} / \mathrm{L}$ and as previously discussed the oxygen percentage $\left(\mathrm{O}_{2} \%\right)$ was well maintained above $60 \%$ according to standard protocol. The Daphnia medium had a lower EC and TDS when compared to the fish medium. This was expected as the reconstituted water is made up of different salts at higher concentrations. The EC ranged between 198 and $420 \mu \mathrm{S} / \mathrm{cm}$ for the Daphnia medium and 621 and $809 \mu \mathrm{S} / \mathrm{cm}$ for the fish medium. The TDS ranged between 104 and $267 \mathrm{mg} / \mathrm{L}$ for the Daphnia medium, while for the fish medium the range was between 309 and $485 \mathrm{mg} / \mathrm{L}$.

3.2. Nanoparticle Exposure Concentration. To verify the concentrations added to each exposure group, total gold concentrations were measured. The nominal ionic gold concentrations and measured concentrations were in close agreement (Figure 1). After a $48 \mathrm{~h}$ and $96 \mathrm{~h}$ period the concentrations were maintained within the start concentration limits. The total gold concentrations in the $\mathrm{nAu}$ exposures showed up to a $20 \%$ difference between nominal and measured gold concentrations.

3.3. Particle Size Distribution. The largest proportion of $\mathrm{nAu}$ (i.e., $>90 \%$ ) in the Daphnia medium across all exposure concentrations showed agglomerations greater than $566 \mathrm{~nm}$ 
TABLE 1: Physicochemical water quality means for selected species in toxicity exposure bioassays with nAu, chloroauric acid, and citrate buffer.

\begin{tabular}{|c|c|c|c|c|c|c|}
\hline Species & $\begin{array}{c}\mathrm{pH} \\
(\min -\max )\end{array}$ & $\begin{array}{c}\text { D.O. }(\mathrm{mg} / \mathrm{L}) \\
(\min -\max )\end{array}$ & $\begin{array}{c}\mathrm{O}_{2}(\%) \\
(\min -\max )\end{array}$ & $\begin{array}{c}\mathrm{EC}(\mu \mathrm{S} / \mathrm{cm}) \\
(\min -\max )\end{array}$ & $\begin{array}{l}\text { Temp. }\left({ }^{\circ} \mathrm{C}\right) \\
(\min -\max )\end{array}$ & $\operatorname{TDS}(\mathrm{mg} / \mathrm{L})$ \\
\hline \multicolumn{7}{|c|}{ Citrate buffer } \\
\hline D. pulex & $\begin{array}{c}7.85 \\
(6.57-8.36)\end{array}$ & $\begin{array}{c}5.43 \\
(4.44-6.08)\end{array}$ & $\begin{array}{c}64.6 \\
(61.7-67.4)\end{array}$ & $\begin{array}{c}339 \\
(309-374)\end{array}$ & $\begin{array}{c}20.5 \\
(20-21.2)\end{array}$ & $\begin{array}{c}171 \\
(156-189)\end{array}$ \\
\hline D. magna & $\begin{array}{c}7.70 \\
(7.6-8.37)\end{array}$ & $\begin{array}{c}7.26 \\
(6.63-8.72)\end{array}$ & $\begin{array}{c}77.0 \\
(62.6-91.4)\end{array}$ & $\begin{array}{c}310 \\
(297-362)\end{array}$ & $\begin{array}{c}19.3 \\
(20-21.9)\end{array}$ & $\begin{array}{c}155 \\
(148-181)\end{array}$ \\
\hline D. rerio & $\begin{array}{c}8.26 \\
(7.10-8.65)\end{array}$ & $\begin{array}{c}4.77 \\
(4.0-6.15)\end{array}$ & $\begin{array}{c}69.6 \\
(60.0-87.2)\end{array}$ & $\begin{array}{c}708 \\
(621-809)\end{array}$ & $\begin{array}{c}23.3 \\
(22.7-23.9)\end{array}$ & $\begin{array}{c}350 \\
(309-398)\end{array}$ \\
\hline O. mossambicus & $\begin{array}{c}7.98 \\
(7.39-8.34)\end{array}$ & $\begin{array}{c}5.04 \\
(4.26-5.9)\end{array}$ & $\begin{array}{c}66.9 \\
(60.2-78.08)\end{array}$ & $\begin{array}{c}708 \\
(530-841)\end{array}$ & $\begin{array}{c}21.4 \\
(20.6-22.1)\end{array}$ & $\begin{array}{c}365 \\
(321-407)\end{array}$ \\
\hline P. reticulata & $\begin{array}{c}7.74 \\
(6.57-8.22)\end{array}$ & $\begin{array}{c}4.85 \\
(3.5-5.77)\end{array}$ & $\begin{array}{c}67.7 \\
(60-77.1)\end{array}$ & $\begin{array}{c}748 \\
(696-810)\end{array}$ & $\begin{array}{c}22.2 \\
(21.6-23.03)\end{array}$ & $\begin{array}{c}373 \\
(316-405)\end{array}$ \\
\hline P. philander & $\begin{array}{c}6.93 \\
(6.01-7.75)\end{array}$ & $\begin{array}{c}5.62 \\
(4.3-6.47)\end{array}$ & $\begin{array}{c}71.7 \\
(60-89.5)\end{array}$ & $\begin{array}{c}732 \\
(665-874)\end{array}$ & $\begin{array}{c}23.1 \\
(22.9-23.2)\end{array}$ & $\begin{array}{c}366 \\
(333-402)\end{array}$ \\
\hline T. sparrmanii & $\begin{array}{c}6.57 \\
(5.81-7.39)\end{array}$ & $\begin{array}{c}4.85 \\
(4.00-5.77)\end{array}$ & $\begin{array}{c}67.9 \\
(60-77.1)\end{array}$ & $\begin{array}{c}674 \\
(612-704)\end{array}$ & $\begin{array}{c}22.1 \\
(21.3-22.6)\end{array}$ & $\begin{array}{c}372 \\
(313-595)\end{array}$ \\
\hline L. aeneus & $\begin{array}{c}7.06 \\
(5.99-7.93) \\
\end{array}$ & $\begin{array}{c}5.93 \\
(4.89-7.07) \\
\end{array}$ & $\begin{array}{c}67.0 \\
(60.3-80.5) \\
\end{array}$ & $\begin{array}{c}680 \\
(638-729) \\
\end{array}$ & $\begin{array}{c}22.5 \\
(21.5-23)\end{array}$ & $\begin{array}{c}346 \\
(324-369) \\
\end{array}$ \\
\hline \multicolumn{7}{|c|}{$\mathrm{nAu}$} \\
\hline D. pulex & $\begin{array}{c}7.66 \\
(7.05-8.7)\end{array}$ & $\begin{array}{c}5.05 \\
(4.4-6.1)\end{array}$ & $\begin{array}{c}63.1 \\
(60.7-72.6)\end{array}$ & $\begin{array}{c}328 \\
(208-420)\end{array}$ & $\begin{array}{c}20.7 \\
(20-21.9)\end{array}$ & $\begin{array}{c}167 \\
(104-220)\end{array}$ \\
\hline D. magna & $\begin{array}{c}7.78 \\
(7.74-8.39)\end{array}$ & $\begin{array}{c}7.23 \\
(6.39-9.28)\end{array}$ & $\begin{array}{c}78.4 \\
(71.7-97.8)\end{array}$ & $\begin{array}{c}309 \\
(293-374)\end{array}$ & $\begin{array}{c}20.2 \\
(20.5-22.2)\end{array}$ & $\begin{array}{c}155 \\
(146-206)\end{array}$ \\
\hline D. rerio & $\begin{array}{c}7.88 \\
(7.13-8.42)\end{array}$ & $\begin{array}{c}4.49 \\
(4.04-6.26)\end{array}$ & $\begin{array}{c}68.1 \\
(60.1-98.7)\end{array}$ & $\begin{array}{c}674 \\
(642-765)\end{array}$ & $\begin{array}{c}22.6 \\
(22.4-23.9)\end{array}$ & $\begin{array}{c}336 \\
(321-412)\end{array}$ \\
\hline O. mossambicus & $\begin{array}{c}7.43 \\
(7.13-7.97)\end{array}$ & $\begin{array}{c}4.68 \\
(4.11-6.24)\end{array}$ & $\begin{array}{c}63.9 \\
(60.0-82.9)\end{array}$ & $\begin{array}{c}681 \\
(621-827)\end{array}$ & $\begin{array}{c}20.8 \\
(20.1-21.1)\end{array}$ & $\begin{array}{c}340 \\
(310-414)\end{array}$ \\
\hline P. reticulata & $\begin{array}{c}7.57 \\
(6.31-8.19)\end{array}$ & $\begin{array}{c}5.97 \\
(4.84-8.26)\end{array}$ & $\begin{array}{c}67.3 \\
(60.0-79.6)\end{array}$ & $\begin{array}{c}743 \\
(658-824)\end{array}$ & $\begin{array}{c}22.2 \\
(21.3-22.6)\end{array}$ & $\begin{array}{c}370 \\
(329-412)\end{array}$ \\
\hline P. philander & $\begin{array}{c}7.24 \\
(6.23-7.79)\end{array}$ & $\begin{array}{c}5.89 \\
(5.14-6.76)\end{array}$ & $\begin{array}{c}73.9 \\
(60.8-92.20)\end{array}$ & $\begin{array}{c}699 \\
(580-762)\end{array}$ & $\begin{array}{c}23.0 \\
(22.9-23.2)\end{array}$ & $\begin{array}{c}350 \\
(328-379)\end{array}$ \\
\hline T. sparrmanii & $\begin{array}{c}7.51 \\
(6.85-8.01)\end{array}$ & $\begin{array}{c}5.69 \\
(4.37-8.26)\end{array}$ & $\begin{array}{c}66.6 \\
(60-79.6)\end{array}$ & $\begin{array}{c}703 \\
(617-754)\end{array}$ & $\begin{array}{c}22.2 \\
(21-22.7)\end{array}$ & $\begin{array}{c}335 \\
(308-378)\end{array}$ \\
\hline L. aeneus & $\begin{array}{c}7.55 \\
(6.29-7.90) \\
\end{array}$ & $\begin{array}{c}5.55 \\
(4.08-7.08) \\
\end{array}$ & $\begin{array}{c}55.9 \\
(60.0-80.7) \\
\end{array}$ & $\begin{array}{c}556 \\
(628-762) \\
\end{array}$ & $\begin{array}{c}22.9 \\
(21.6-23.1) \\
\end{array}$ & $\begin{array}{c}275 \\
(314-381) \\
\end{array}$ \\
\hline \multicolumn{7}{|c|}{ Chloroauric acid } \\
\hline D. pulex & $\begin{array}{c}7.90 \\
(6.93-8.95)\end{array}$ & $\begin{array}{c}5.35 \\
(4.35-6.13)\end{array}$ & $\begin{array}{c}66.3 \\
(62.7-71.5)\end{array}$ & $\begin{array}{c}344 \\
(198-382)\end{array}$ & $\begin{array}{c}20.6 \\
(20-22)\end{array}$ & $\begin{array}{c}176 \\
(104-267)\end{array}$ \\
\hline D. magna & $\begin{array}{c}8.22 \\
(7.59-8.43)\end{array}$ & $\begin{array}{c}7.57 \\
(6.4-9.78)\end{array}$ & $\begin{array}{c}83.3 \\
(62.5-99.7)\end{array}$ & $\begin{array}{c}332 \\
(296-381)\end{array}$ & $\begin{array}{c}21.6 \\
(20.4-22.4)\end{array}$ & $\begin{array}{c}168 \\
(148-259)\end{array}$ \\
\hline D. rerio & $\begin{array}{c}7.92 \\
(6.24-8.67)\end{array}$ & $\begin{array}{c}4.98 \\
(4.2-6.044)\end{array}$ & $\begin{array}{c}72.0 \\
(62.8-85.3)\end{array}$ & $\begin{array}{c}677 \\
(621-739)\end{array}$ & $\begin{array}{c}23.0 \\
(21.8-23.7)\end{array}$ & $\begin{array}{c}350 \\
(311-485)\end{array}$ \\
\hline O. mossambicus & $\begin{array}{c}7.56 \\
(6.45-7.98)\end{array}$ & $\begin{array}{c}5.86 \\
(4.23-7.85)\end{array}$ & $\begin{array}{c}72.3 \\
(60.2-84.8)\end{array}$ & $\begin{array}{c}700 \\
(620-806)\end{array}$ & $\begin{array}{c}21.3 \\
(20.6-21.6)\end{array}$ & $\begin{array}{c}350 \\
(310-403)\end{array}$ \\
\hline P. reticulata & $\begin{array}{c}7.33 \\
(6.26-8.27)\end{array}$ & $\begin{array}{c}5.63 \\
(4.8-7.67)\end{array}$ & $\begin{array}{c}73.6 \\
(60.9-81)\end{array}$ & $\begin{array}{c}711 \\
(616-838)\end{array}$ & $\begin{array}{c}21.7 \\
(20.9-22.4)\end{array}$ & $\begin{array}{c}355 \\
(308-419)\end{array}$ \\
\hline P. philander & $\begin{array}{c}7.62 \\
(7.36-8.04)\end{array}$ & $\begin{array}{c}6.82 \\
(4.49-8.26)\end{array}$ & $\begin{array}{c}77.0 \\
(62.1-99)\end{array}$ & $\begin{array}{c}702 \\
(603-736)\end{array}$ & $\begin{array}{c}23.1 \\
(22.3-23.5)\end{array}$ & $\begin{array}{c}352 \\
(301-400)\end{array}$ \\
\hline T. sparrmanii & $\begin{array}{c}7.24 \\
(6.26-8.14)\end{array}$ & $\begin{array}{c}5.61 \\
(4.6-7.67)\end{array}$ & $\begin{array}{c}73.4 \\
(62.3-81)\end{array}$ & $\begin{array}{c}633 \\
(545-792)\end{array}$ & $\begin{array}{c}21.6 \\
(21.0-22.1)\end{array}$ & $\begin{array}{c}388 \\
(308-436)\end{array}$ \\
\hline L. aeneus & $\begin{array}{c}7.77 \\
(7.36-8.04)\end{array}$ & $\begin{array}{c}5.90 \\
(4.46-8.24)\end{array}$ & $\begin{array}{c}76.7 \\
(61.8-99.4)\end{array}$ & $\begin{array}{c}700 \\
(603-794)\end{array}$ & $\begin{array}{c}23.1 \\
(22.3-23.6)\end{array}$ & $\begin{array}{c}350 \\
(301-398)\end{array}$ \\
\hline
\end{tabular}




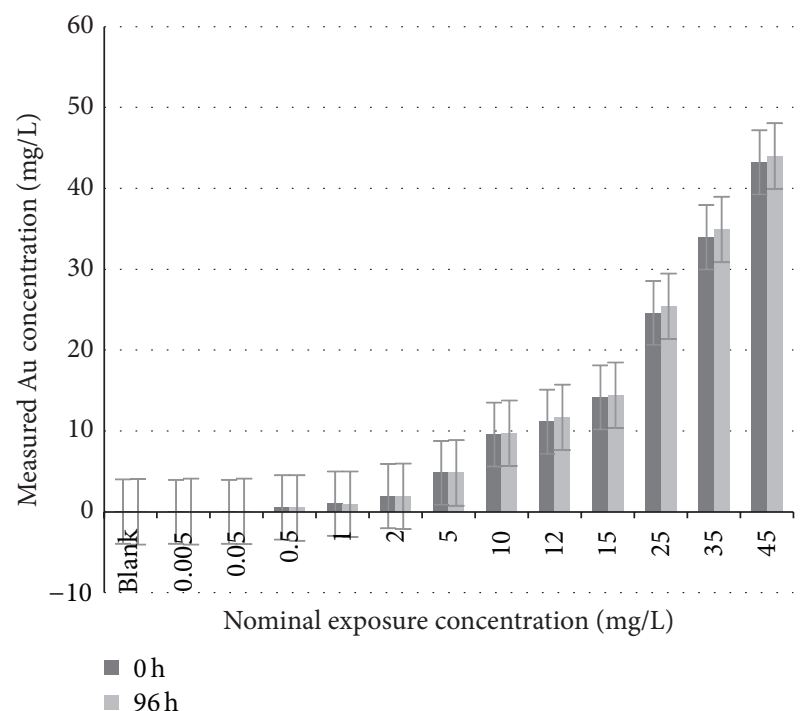

(a)

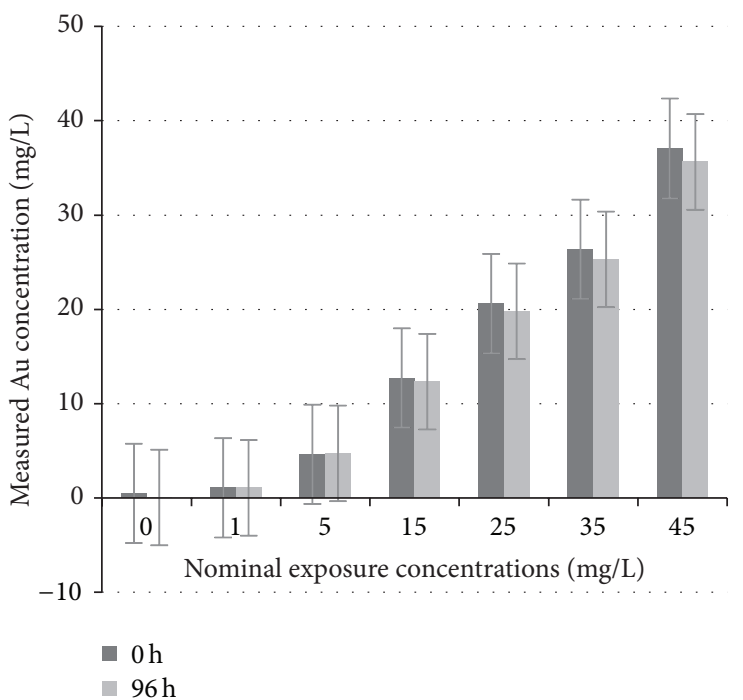

(b)

Figure 1: Mean measured gold concentrations $(\mathrm{mg} / \mathrm{L}) \pm$ standard deviation of the (a) ionic gold $\left(\mathrm{HAuCl}_{4}\right)$ and $(\mathrm{b}) \mathrm{nAu}$ exposures at all exposure concentrations used in this study.

TABLE 2: Size distribution of gold nanoparticles across all concentrations in Daphnia medium.

\begin{tabular}{lccc}
\hline & nAu size Daphnia medium & \\
Concentration & $\mathrm{nm}$ & St. dev. & \% intensity \\
\hline $25 \mathrm{mg} / \mathrm{L}$ & 565.6 & 87.82 & 93.9 \\
$35 \mathrm{mg} / \mathrm{L}$ & 827.45 & 56.50 & 92.5 \\
$45 \mathrm{mg} / \mathrm{L}$ & 3175.5 & 443.35 & 93 \\
\hline
\end{tabular}

(Table 2). As the exposure concentration increased, so did the average sizes of the agglomeration; for example, in the $45 \mathrm{mg} / \mathrm{L}$ exposure the average sizes were $3175.5 \mathrm{~nm}$ (Table 2).

In contrast to the $\mathrm{nAu}$ particle aggregation/agglomeration in Daphnia media, the dynamic light scattering (DLS) indicated that the size distribution in fish media is represented by two peaks in terms of percentage intensity (Figure 2). The particle size distribution is therefore not presented as the average size as there were distinct differences and this would not give an accurate indication of the sizes available for biological uptake. Therefore the size distribution is represented as two dominant size classes per concentration with the corresponding percentage intensities at $0 \mathrm{~h}$ as well as at $96 \mathrm{~h}$.

The nanoparticle size distribution was determined at $0 \mathrm{~h}$ and again at $96 \mathrm{~h}$ to observe any changes in aggregation over time. Results are presented by indicating the main size distribution classes in terms of the percentage contribution after $0 \mathrm{~h}$ and $96 \mathrm{~h}$. At $0 \mathrm{~h} \mathrm{nAu} \mathrm{exposures} \mathrm{there} \mathrm{were} \mathrm{two}$ dominant size distribution classes, that is, sizes representing $>60 \%$ intensity and less than $40 \%$ intensity (Figure 3 ). The same was shown at $96 \mathrm{~h}$ where more than $55 \%$ of nanoparticles had the indicated size. In four concentrations $(10 \mathrm{mg} / \mathrm{L}$, $20 \mathrm{mg} / \mathrm{L}, 25 \mathrm{mg} / \mathrm{L}$, and $45 \mathrm{mg} / \mathrm{L}$ ) the particles had less than $45 \%$ percentage intensity of the indicated size.

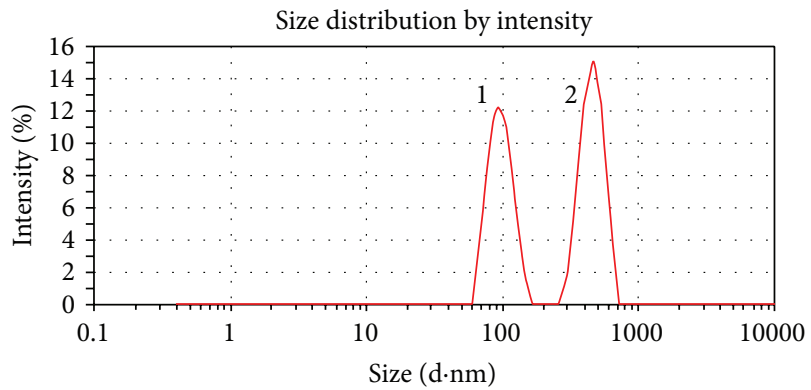

FIgURE 2: Raw data sheet showing two peaks of $Z$-average size $(\mathrm{d} \cdot \mathrm{nm})$ of gold nanoparticles in aquatic medium where peak 1 shows a size of $96.89 \mathrm{~nm}( \pm 45.5 \mathrm{~nm})$ and peak 2 shows a size of $455.6 \mathrm{~nm}$ $( \pm 54.5 \mathrm{~nm})$.

At $0 \mathrm{~h}$ in the $5 \mathrm{mg} / \mathrm{L}$ concentration $89 \%$ of the sample had a size distribution of $150.7 \mathrm{~nm}$ and $12 \%$ of nanoparticles were $12.64 \mathrm{~nm}$. After $96 \mathrm{~h}$ more than $90 \%$ of particles were $133.7 \mathrm{~nm}$ in size. At $10 \mathrm{mg} / \mathrm{L}$ all particles measured in the sample were around $75.79 \mathrm{~nm}$ while after $96 \mathrm{~h}$ the particles (82.7\%) had agglomerated to $986.4 \mathrm{~nm}$ while $17.3 \%$ remained approximately $79.64 \mathrm{~nm}$ in diameter. At $15 \mathrm{mg} / \mathrm{L}, 89 \%$ were in the size range of $89.49 \mathrm{~nm}$, while $11 \%$ were at $15.51 \mathrm{~nm}$. After $96 \mathrm{~h}$ particles had all aggregated to $96.6 \mathrm{~nm}$. At the onset of the $20 \mathrm{mg} / \mathrm{L}$ exposure $88 \%$ of the particles had aggregated to $127.9 \mathrm{~nm}$ and $12.2 \%$ to $17.12 \mathrm{~nm}$ in diameter. After $96 \mathrm{~h} 64 \%$ of the sample had agglomerated to $894.5 \mathrm{~nm}$ and $36 \%$ of the sample was $121.5 \mathrm{~nm}$ in size. At the $25 \mathrm{mg} / \mathrm{L}$ concentration just over half $(59.6 \%)$ of the sample was $298.4 \mathrm{~nm}$ in size while just under half $(40.4 \%)$ of the sample was $71.48 \mathrm{~nm}$. After $96 \mathrm{~h}$ the same ratio was maintained where $54.5 \%$ of the sample had a size of $455.6 \mathrm{~nm}$ and $45.5 \%$ had a size of $96.89 \mathrm{~nm}$. At $30 \mathrm{mg} / \mathrm{L}$ the prevalence was $72.3 \%$ distribution of $163.1 \mathrm{~nm}$ particles and $27.7 \%$ at $40.27 \mathrm{~nm}$, while after $96 \mathrm{~h}$ 


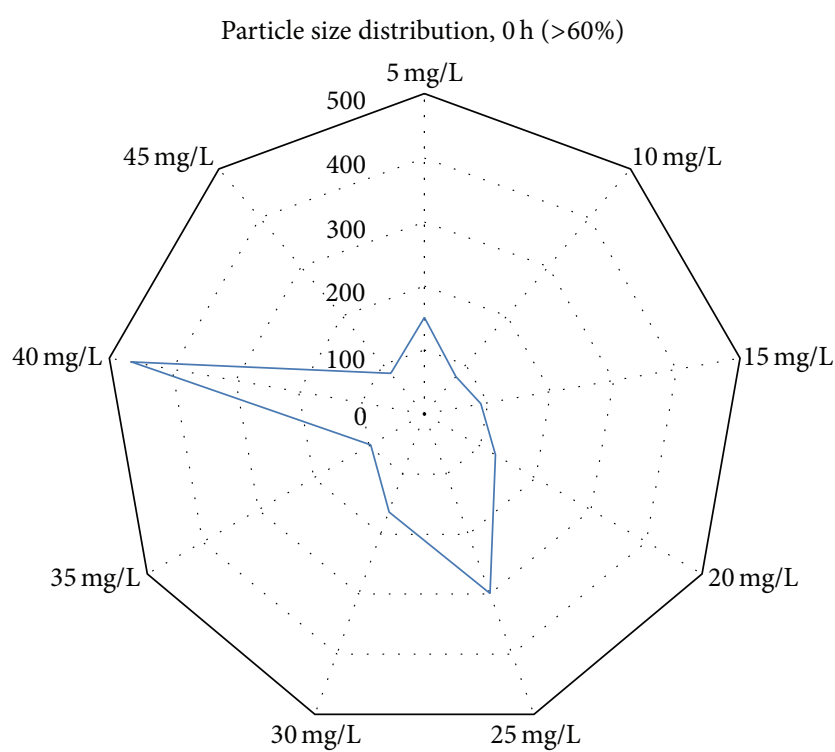

$-0 \mathrm{~h}$

(a)

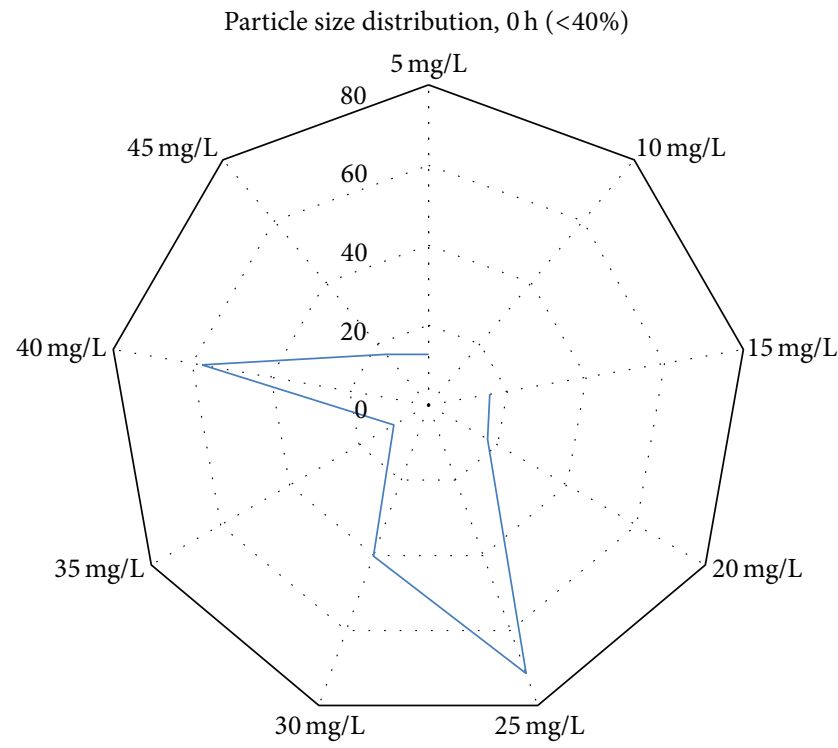

$-0 \mathrm{~h}$

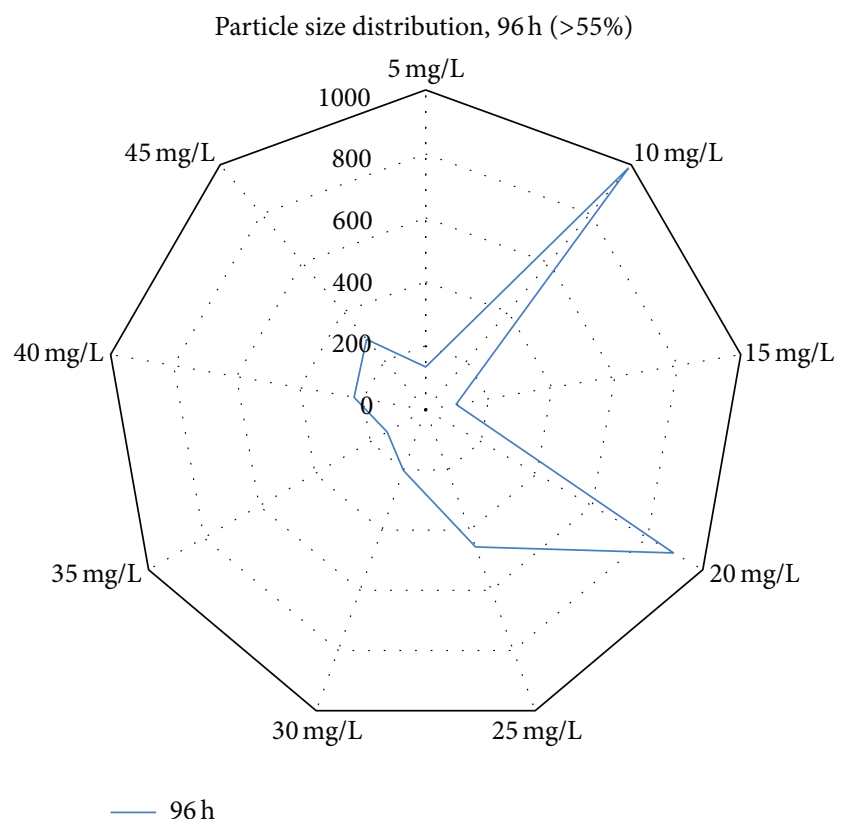

(b)

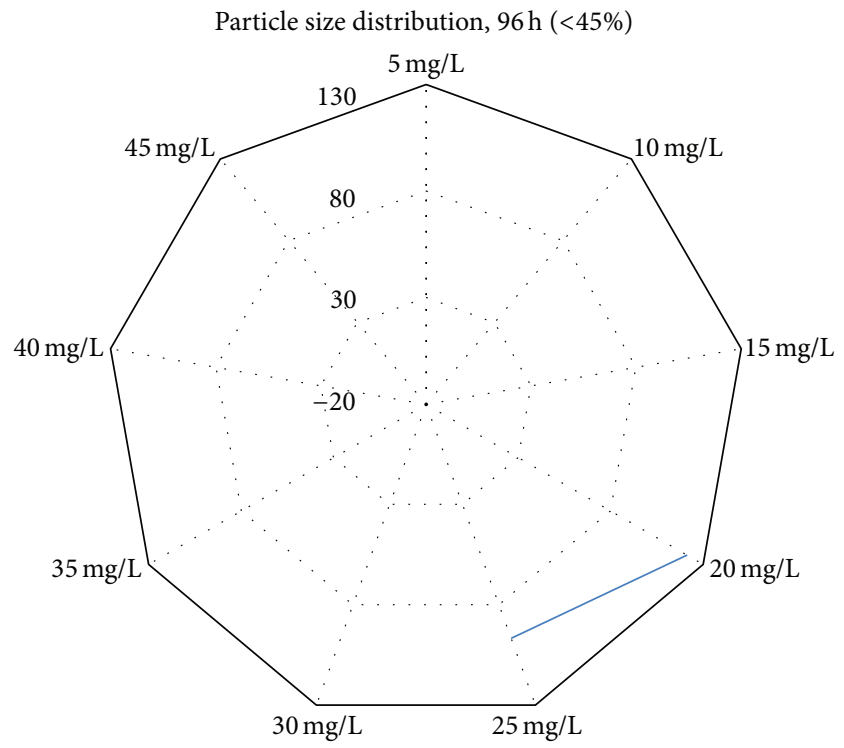

$-96 \mathrm{~h}$

(c)

(d)

Figure 3: Particle size distribution (nm) of nAu with a percentage intensity of (a) more than $60 \%$ at $0 \mathrm{~h}$ and (b) less than $40 \%$ at $0 \mathrm{~h}$ as well as (c) more than $55 \%$ at $96 \mathrm{~h}$ and (d) less than $45 \%$ at $96 \mathrm{~h}$.

all particles had agglomerated to $201.5 \mathrm{~nm}$. The $35 \mathrm{mg} / \mathrm{L}$ concentration revealed that $91 \%$ of the sample had aggregated to $96.89 \mathrm{~nm}$ and $9 \%$ of the sample remained around $14 \mathrm{~nm}$ in size. After $96 \mathrm{~h}$ all particles had aggregated to $138.2 \mathrm{~nm}$. The $40 \mathrm{mg} / \mathrm{L}$ concentration showed an immediate aggregation at $0 \mathrm{~h}$ where $57.4 \%$ of the sample was $464.9 \mathrm{~nm}$ and $42.6 \%$ of the sample was $57.55 \mathrm{~nm}$ in size. After $96 \mathrm{~h}$ all sample measured contained a uniform size of $226.9 \mathrm{~nm}$. At the highest concentration, $45 \mathrm{mg} / \mathrm{L}, 79.9 \%$ of the sample had particles $82.52 \mathrm{~nm}$ in size and $15 \%$ remained around the original size of $14 \mathrm{~nm}$. After $96 \mathrm{~h}$ the prevalence of particles at $288 \mathrm{~nm}$ was $87.7 \%$ and $12.3 \%$ were $63.05 \mathrm{~nm}$ in size. In the $40 \mathrm{mg} / \mathrm{L}$ and $45 \mathrm{mg} / \mathrm{L}$ concentration $\mathrm{nAu}$ had precipitated out of solution and were visible to the naked eye. These agglomerates were in the millimetre size range and could not be measured on the DLS instrument.

At $0 \mathrm{~h}$ there was a clear increase in size of $\mathrm{nAu}$ aggregations and agglomeration at concentrations of $25 \mathrm{mg} / \mathrm{L}$ and 
TABLE 3: Zeta potential $(\mathrm{mV})$ of the $\mathrm{nAu}$ in the Daphnia medium across exposure concentrations.

\begin{tabular}{lccccrr}
\hline $\mathrm{nAu}$ & $1 \mathrm{mg} / \mathrm{L}$ & $5 \mathrm{mg} / \mathrm{L}$ & \multicolumn{1}{c}{$\begin{array}{l}15 \mathrm{mg} / \mathrm{L} \\
\text { Zeta potential }[\mathrm{mV}]\end{array}$} & \multicolumn{5}{c}{$45 \mathrm{mg} / \mathrm{L} / \mathrm{L} g / \mathrm{L}$} & \\
\hline $0 \mathrm{~h}$ & $-8.74 \pm 2.91$ & $-3.07 \pm 1.58$ & $-8.13 \pm 9.72$ & $-17.16 \pm 22.92$ & $-10.27 \pm 2.12$ & $-9.40 \pm 0.54$ \\
$48 \mathrm{~h}$ & -2.03 & $-7.17 \pm 4.30$ & -16.10 & $-8.50 \pm 0.92$ & $-2.78 \pm 0.80$ & $-4.14 \pm 1.23$ \\
\hline
\end{tabular}

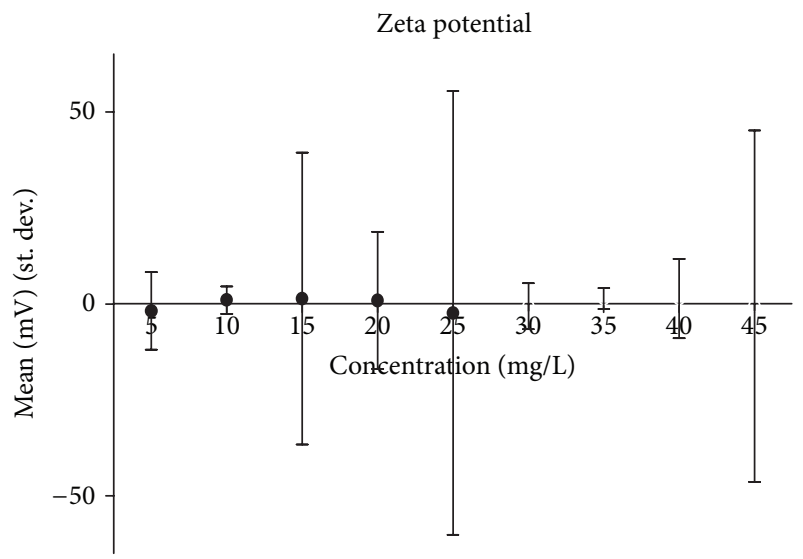

(a)

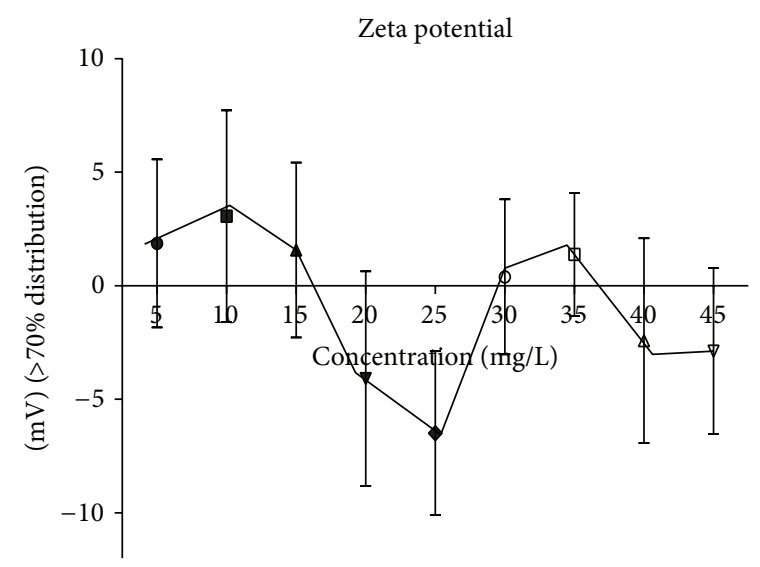

(b)

FIGURE 4: (a) The zeta potential ( $\mathrm{mV}$ ) average peak reading across all concentrations. (b) The zeta potential ( $\mathrm{mV})$ reading where the peak had greater-than-seventy-percent distribution measured across all concentrations.

$40 \mathrm{mg} / \mathrm{L}$ when compared to other concentrations. But after $96 \mathrm{~h}$ the $20 \mathrm{mg} / \mathrm{L}$ and $25 \mathrm{mg} / \mathrm{L}$ concentrations still showed agglomerations increasing in size and dispersion in the media while concentrations $30 \mathrm{mg} / \mathrm{L}$ and above showed no or lower measured sizes, which is attributed to particle precipitation.

\subsection{Particle Charge (Zeta Potential). The EC differed for the} Daphnia and fish media based on the salts used to make up the reconstituted water. For the Daphnia medium the zeta potential ranged between $-3.07 \mathrm{mV}$ and $-17.16 \mathrm{mV}$ (Table 3) with all values across all time intervals being negative. At $5 \mathrm{mg} / \mathrm{L}$ and $15 \mathrm{mg} / \mathrm{L}$ exposures the zeta potential decreased even further after $48 \mathrm{~h}$ while at all other concentrations the zeta potential became more positive.

For the fish medium there was much greater variation (as observed in the increase in the standard deviation) of the measured zeta potential. The standard deviation (Figure 4(a)) ranged between $57.8 \mathrm{mV}$ and $-54.9 \mathrm{mV}$. This is related to the large difference in size distribution as shown in Figure 3. In Figure 4(b) the zeta potential data were limited to those that represent $70 \%$ of the dominant distribution (i.e., the outliers were removed). The dominant zeta potential at $20 \mathrm{mg} / \mathrm{L}, 25 \mathrm{mg} / \mathrm{L}, 40 \mathrm{mg} / \mathrm{L}$, and $45 \mathrm{mg} / \mathrm{L}$ was negative, that is, $-4.09 \mathrm{mV},-6.49 \mathrm{mV},-2.42 \mathrm{mV}$, and $-2.88 \mathrm{mV}$, respectively. At all other concentrations the charge was positive with the highest at $10 \mathrm{mg} / \mathrm{L}(3.06 \mathrm{mV})$.

3.5. Surface Functionality. The FTIR results revealed two distinct peaks (Figure 5). One of the peaks was identified as a hydroxyl group and further analyses of the black particle aggregates were carried out on dried sample to eliminate any interference in the spectrum of the water suspension. The first peak $\left( \pm 1632 \mathrm{~cm}^{-1}\right)$ was identified as an organic nitrate or carbon double bond aromatic stretch. The second peak $\left( \pm 3343 \mathrm{~cm}^{-1}\right)$ was identified as a hydroxyl group, H-bonded $\mathrm{OH}$ stretch $\left(3570-3200 \mathrm{~cm}^{-1}\right.$ (broad) $3400-3200 \mathrm{~cm}^{-1}$ ) or a normal "polymeric" $\mathrm{OH}$ stretch, which indicates interaction with the water medium.

3.6. Gold Nanoparticle Aggregation and Agglomeration Patterns. The TEM results revealed a better understanding of the size distribution patterns. As defined by Klaine et al. [35] nanoparticle groupings of less than $150 \mathrm{~nm}$ were referred to as aggregates and those larger than $150 \mathrm{~nm}$ were seen as agglomerates. In the stock solution $(1000 \mathrm{mg} / \mathrm{L})$ the citrate capping was visible around the $\mathrm{nAu}$ especially at a higher magnification. It was clear that particles were separated from one another while present in the citrate buffer capping agent (Figure 6(a)). A live fast Fourier transform (FFT) image was taken to verify that the particles were aligned in a crystal lattice formation as is typical of nano metals (Figure 6(b)). At $0 \mathrm{~h}$ dispersed $\mathrm{nAu}$ were observed in all exposure concentrations. However, after $96 \mathrm{~h}$ this was only possible to identify dispersed particles at $5 \mathrm{mg} / \mathrm{L}$ and $10 \mathrm{mg} / \mathrm{L}$ exposure concentrations. For the $40 \mathrm{mg} / \mathrm{L}$ and $45 \mathrm{mg} / \mathrm{L}$ exposures it was apparent that after $24 \mathrm{~h}$ the $\mathrm{nAu}$ started to agglomerate and precipitate out of solution. At $5 \mathrm{mg} / \mathrm{L} \mathrm{nAu}$ were much more difficult to find on the dried copper grid but were present and showed aggregations of small groups (Figure 6(c)) as well as string-like aggregates (Figure $6(\mathrm{~d})$ ), while at $10 \mathrm{mg} / \mathrm{L}$ the string-like aggregates were still present but more were present (Figure 6(e)) and had started aggregating at $122.87 \mathrm{~nm}$ onto 


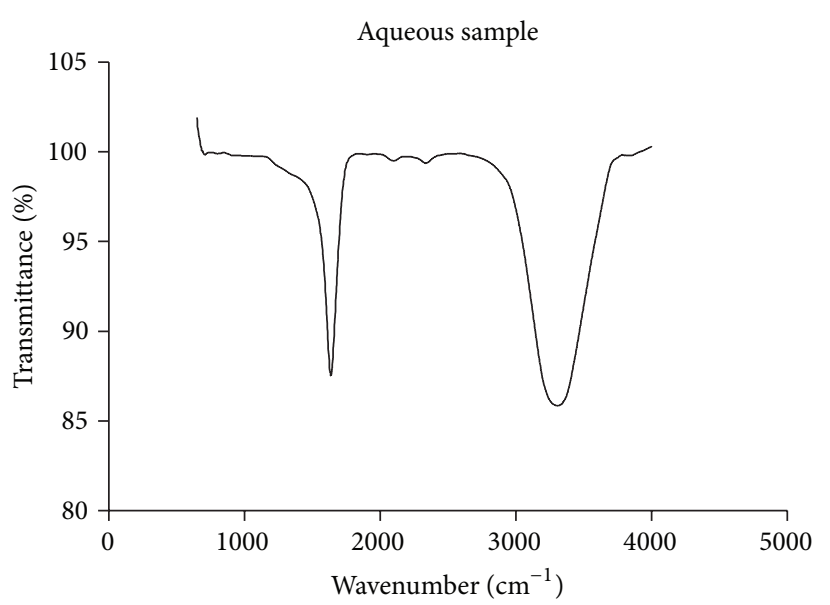

(a)

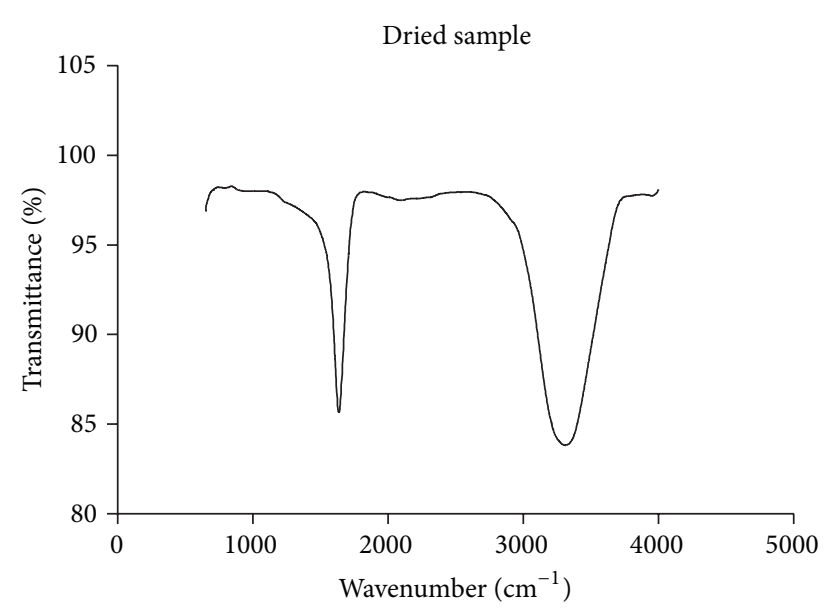

(b)

FIGURE 5: (a) The FTIR spectra results of the highest concentration of gold nanoparticle in an aqueous solution. (b) FTIR spectra results of the dried gold nanoparticle sample in the highest concentration to eliminate $\mathrm{OH}$ interference from the solution.

the string-like structures as though a skeletal backbone had been formed (Figure 6(f)).

In the $20 \mathrm{mg} / \mathrm{L}$ exposure there were two major types of agglomerates noted; these were skeletal-like agglomerates which reached approximately $352.1 \mathrm{~nm}$ in length (Figure 7(a)) and smaller aggregates which were quite prevalent and easy to find throughout the dried copper grid and which showed an approximate size of around $73.67 \mathrm{~nm}$. When observing $30 \mathrm{mg} / \mathrm{L} \mathrm{nAu}$ concentrations it was quite clear that the skeletal backbone structures were starting to attach to one another as seen in Figure 7(c). Seeing that the conformation was stable the smaller agglomerates $(152.19 \mathrm{~nm})$ started attaching the open spaces in between and particle agglomerates were as large as $430.78 \mathrm{~nm}$ (Figure 7(d)). It appears that at $40 \mathrm{mg} / \mathrm{L}$ the larger agglomerates as seen in $30 \mathrm{mg} / \mathrm{L}$ started attaching to one another (Figure 7(e)); the skeletal backbone has now been filled and the nAu aggregate into an accumulation of particles forming large agglomerates of up to $2000 \mathrm{~nm}$ visible on TEM. At these concentrations agglomerates were also visible to the naked eye.

3.7. Acute Toxicity Testing. No mortalities were recorded in the controls and the dispersant controls (i.e., mortalities were below $10 \%$ ). It was not possible to calculate LC50 values for the $48 \mathrm{~h} \mathrm{D}$. pulex and $96 \mathrm{~h} \mathrm{D}$. rerio, O. mossambicus, $P$. philander, and $L$. aeneus $\mathrm{nAu}$ exposures (Table 4). The $\mathrm{nAu}$ LC50 values for $D$. pulex, T. sparrmanii, and $P$. reticulata were $7.31 \mathrm{mg} / \mathrm{L}, 12.08 \mathrm{mg} / \mathrm{L}$, and $52.57 \mathrm{mg} / \mathrm{L}$, respectively. The ionic gold LC50 values for the test organisms ranged between $0.01 \mathrm{mg} / \mathrm{L}$ for $D$. pulex and $20.58 \mathrm{mg} / \mathrm{L}$ for $P$. reticulata. For the nAu T. sparrmanii was the most sensitive, while for ionic gold $D$. pulex was the most sensitive aquatic organism tested. Based on the LC50 values it was evident that the species were much more sensitive to ionic gold than $\mathrm{nAu}$ exposure. The toxicity of ionic gold was significantly greater $(p<0.05)$ to $D$. pulex compared to all the species tested. Both Daphnia species were significantly more sensitive to ionic gold than the fish species. The fish species L. aeneus, D. rerio, and P. philander were significantly $(p<0.05)$ more sensitive than the other species. The NOEC and LOEC data were established from the mortality results and are depicted in Table 4 . The LOECs observed for nAu for D. pulex, D. magna, D. rerio, P. reticulata, P. philander, T. sparrmanii, and L. aeneus were 10, 5, >15, 35, 25 , and $5 \mathrm{mg} / \mathrm{L}$, respectively, with $O$. mossambicus showing no mortalities at any of the exposure concentrations. No effect concentrations were recorded at $1,5,<15$, and $<35 \mathrm{mg} / \mathrm{L}$, respectively. The LOECs for ionic gold were $0.0005,0.01,5$, $5,10,10,2$, and $1 \mathrm{mg} / \mathrm{L}$ for $D$. pulex, D. magna D. rerio, $O$. mossambicus, $P$. reticulata, $P$. philander, T. sparrmanii, and $L$. aeneus.

3.8. Species Sensitivity Distribution. The cumulative mortality rates of the organisms over the $48 \mathrm{~h}$ and $96 \mathrm{~h}$ exposure periods for both nAu and ionic gold are depicted in Figures 8 and 9 , respectively. The cumulative percentages are based on the mortalities recorded at all exposure concentrations during the particular exposure period and provide further indication of the sensitivity of the particular species. The low toxicity of $\mathrm{nAu}$ exposure is clearly visible (Figure 8 ) with only $T$. sparrmanii displaying a $20 \%$ toxicity response after $36-48 \mathrm{~h}$ exposure and maximum mortality of $48 \%$ after $96 \mathrm{~h}$. The rest of the species had a mortality rate lower than $10 \%$. For most species exposed to ionic gold $50 \%$ mortality was reached between $12 \mathrm{~h}$ and $24 \mathrm{~h}$ with $O$. mossambicus, D. rerio, and $L$. aeneus displaying the highest immortality of $57 \%, 68 \%$, and $78 \%$ (Figure 9). Both species of Daphnia show 75\% mortality after $24 \mathrm{~h}$.

Seven data points are generally required to generate a meaningful SSD for any given chemical [46]. Since it was not possible to calculate nAu LC50 values for all the species tested, an SSD was constructed based on the toxicity data that were available. The SSD for $\mathrm{nAu}$ (Figure 10) was generated based on the limited acute toxicity data generated during this study and the few data published in literature [40, 41]. 


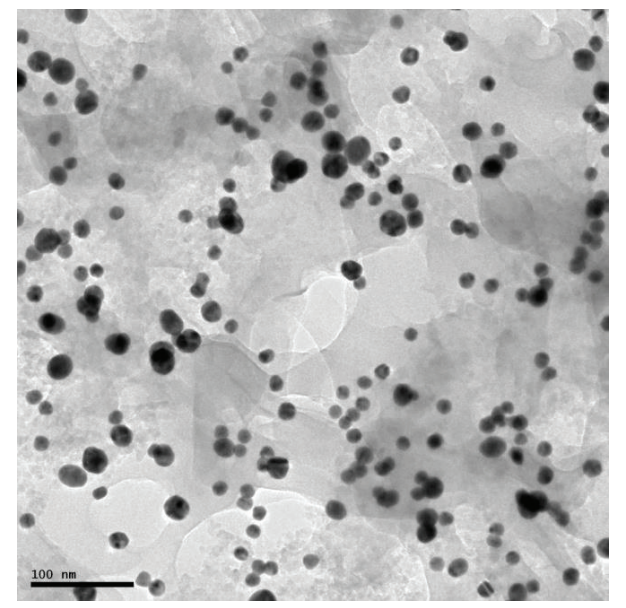

(a)

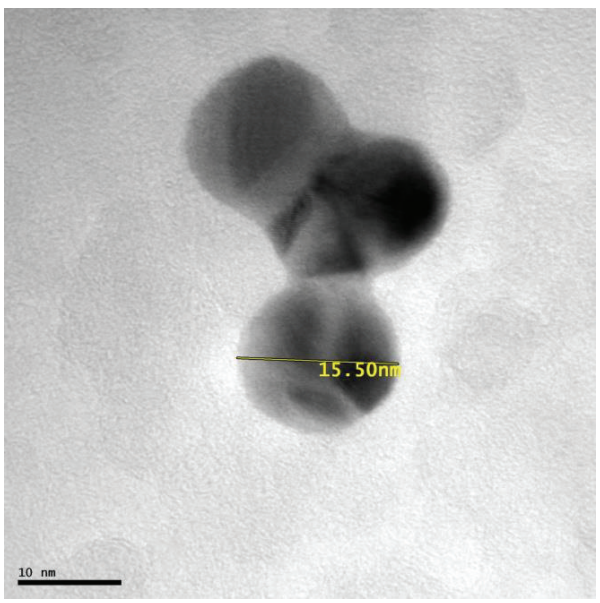

(c)

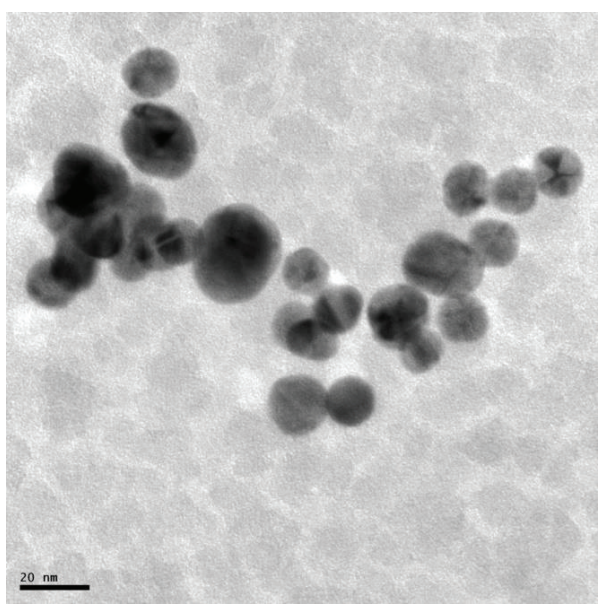

(e)

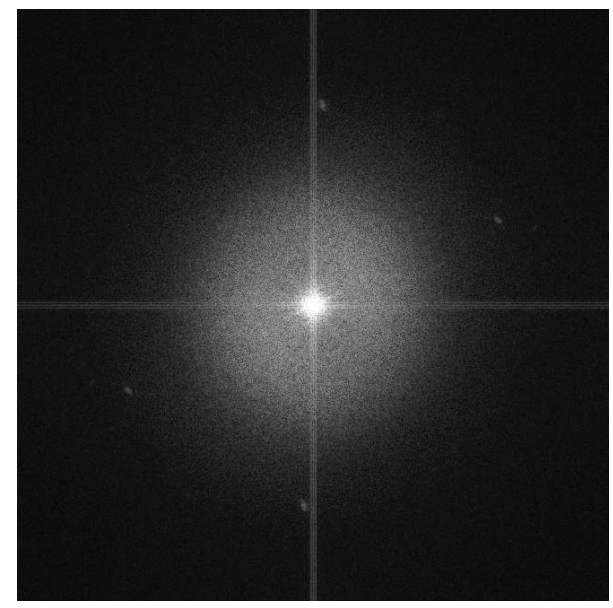

(b)

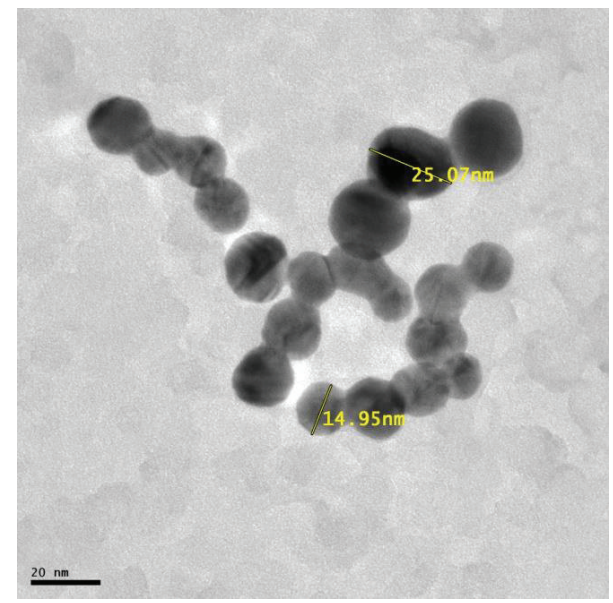

(d)

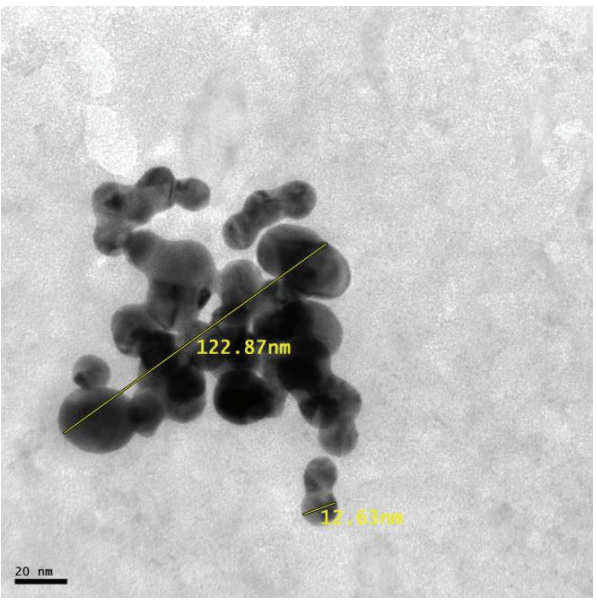

(f)

FIGURE 6: (a) A TEM micrograph of a drop of the concentrated citrate capped $1000 \mathrm{mg} / \mathrm{L}$ concentration gold nanoparticle stock solution. (b) An FFT image of the nAu to confirm the presence of a crystal lattice. ((c) and (d)) A TEM micrograph of the $5 \mathrm{mg} / \mathrm{L}$ gold nanoparticle concentration showing average aggregations and measurements. ((e) and (f)) A TEM micrograph of the $10 \mathrm{mg} / \mathrm{L}$ gold nanoparticle concentration showing average aggregations and measurements. 


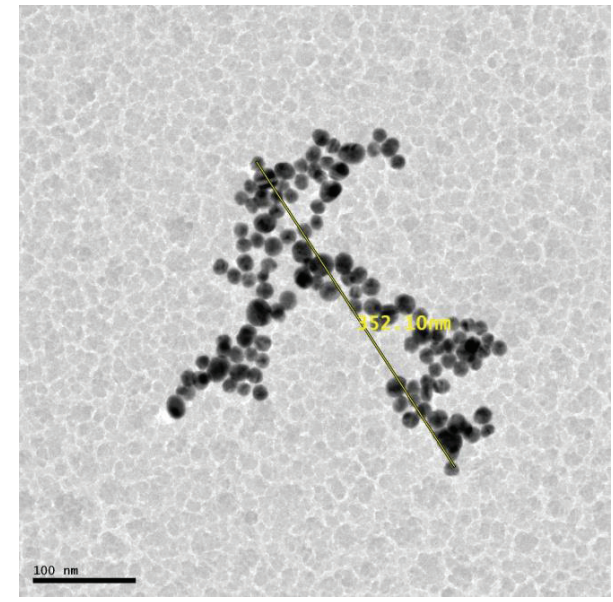

(a)

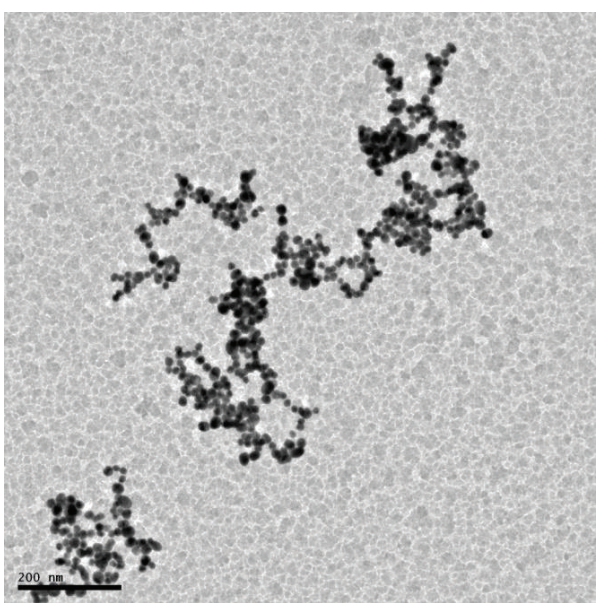

(c)

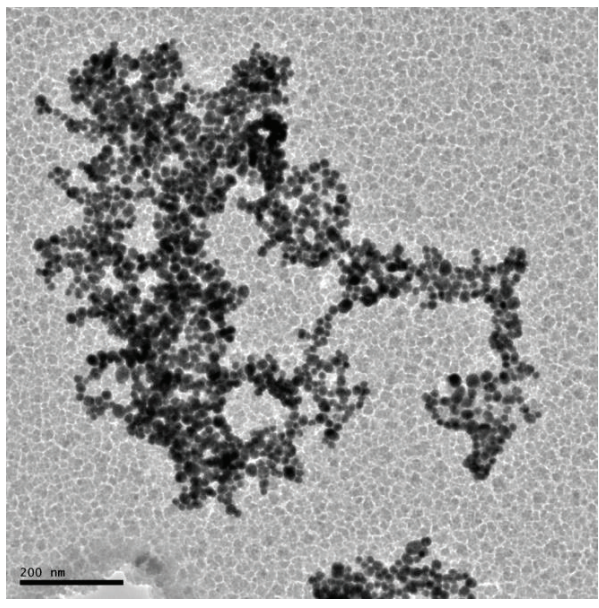

(e)

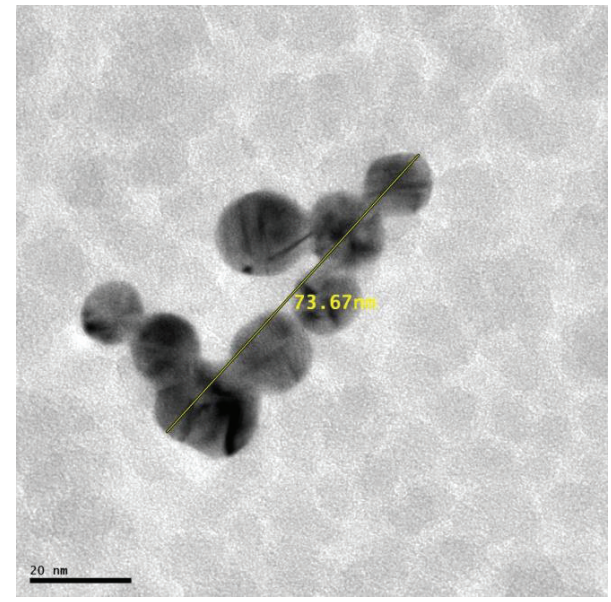

(b)

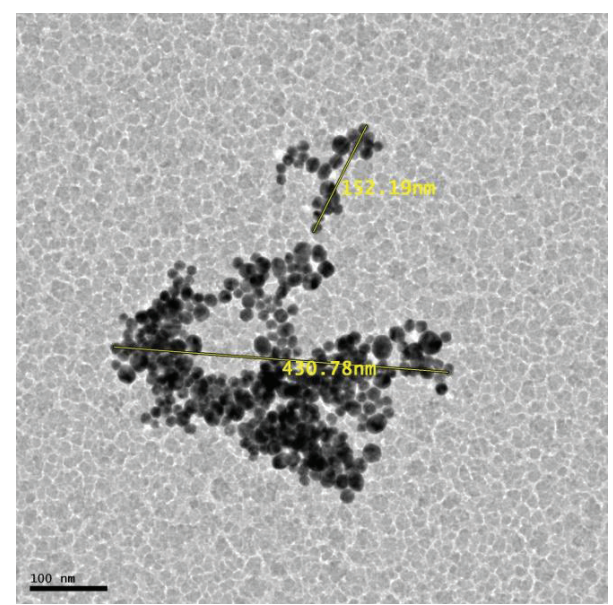

(d)

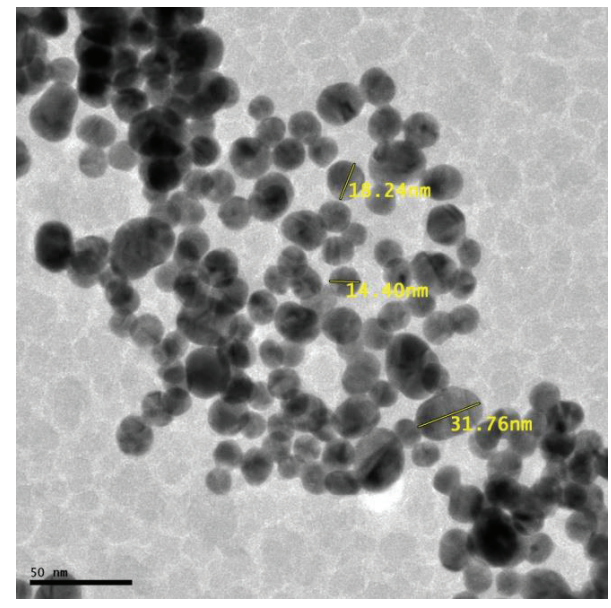

(f)

FIGURE 7: ((a) and (b)) A TEM micrograph of the $20 \mathrm{mg} / \mathrm{L} \mathrm{nAu}$ concentration showing average aggregations and measurements. ((c) and (d)) A TEM micrograph of the $30 \mathrm{mg} / \mathrm{L}$ gold nanoparticle concentration showing average aggregations and measurements. ((e) and (f)) A TEM micrograph of the $40 \mathrm{mg} / \mathrm{L}$ gold nanoparticle concentration showing average aggregations and measurements. 
TABLE 4: Median lethal concentrations for 50\% (LC50) effect and the corresponding 95\% confidence intervals for test organisms exposed to $\mathrm{nAu}$ and chloroauric acid.

\begin{tabular}{|c|c|c|c|c|c|}
\hline \multirow{2}{*}{ Species } & \multirow{2}{*}{ Duration/endpoint } & \multicolumn{2}{|r|}{ LC50 (mg/L) (95\% CI) } & \multirow{2}{*}{ NOEC } & \multirow{2}{*}{ LOEC } \\
\hline & & Mean & Upper \& lower confidence limits (mg/L) & & \\
\hline \multicolumn{6}{|c|}{$\mathrm{nAu}$} \\
\hline D. pulex & $48 \mathrm{~h}$ & 75.31 & * & 1 & 10 \\
\hline D. magna & $48 \mathrm{~h}$ & & Could not be calculated & 0 & 5 \\
\hline D. rerio & $96 \mathrm{~h}$ & & Could not be calculated & $<15$ & $>15$ \\
\hline O. mossambicus & $96 \mathrm{~h}$ & \multicolumn{4}{|c|}{ No mortalities } \\
\hline P. reticulata & $96 \mathrm{~h}$ & 52.57 & * & $<35$ & 35 \\
\hline P. philander & $96 \mathrm{~h}$ & \multicolumn{2}{|r|}{ Could not be calculated } & 5 & 10 \\
\hline T. sparrmanii & $96 \mathrm{~h}$ & 12.08 & * & 5 & 25 \\
\hline L. aeneus & $96 \mathrm{~h}$ & \multicolumn{2}{|r|}{ Could not be calculated } & 1 & 5 \\
\hline \multicolumn{6}{|c|}{ Chloroauric acid } \\
\hline \multirow[t]{2}{*}{ D. pulex } & \multirow[t]{2}{*}{$48 \mathrm{~h}$} & \multirow[t]{2}{*}{0.01} & 0 & \multirow[t]{2}{*}{$<0.0005$} & \multirow[t]{2}{*}{0.0005} \\
\hline & & & 0.02 & & \\
\hline \multirow{2}{*}{ D. magna } & \multirow{2}{*}{$48 \mathrm{~h}$} & \multirow{2}{*}{0.15} & 0.29 & \multirow{2}{*}{$<0.005$} & \multirow{2}{*}{0.01} \\
\hline & & & 0.08 & & \\
\hline \multirow[t]{2}{*}{ D. rerio } & \multirow[t]{2}{*}{$96 \mathrm{~h}$} & \multirow[t]{2}{*}{4.85} & 3.62 & \multirow[t]{2}{*}{$<1$} & \multirow[t]{2}{*}{5} \\
\hline & & & 6.49 & & \\
\hline \multirow[t]{2}{*}{ O. mossambicus } & \multirow{2}{*}{$96 \mathrm{~h}$} & \multirow{2}{*}{11.30} & 15.89 & \multirow{2}{*}{$<1$} & \multirow{2}{*}{5} \\
\hline & & & 8.03 & & \\
\hline \multirow{2}{*}{ P. reticulata } & \multirow{2}{*}{$96 \mathrm{~h}$} & 20.58 & 24.15 & $<10$ & 10 \\
\hline & & 20.00 & 17.54 & & \\
\hline P. philander & $96 \mathrm{~h}$ & 7.53 & 8.18 & $<10$ & 10 \\
\hline & & & 6.94 & & \\
\hline T. sparrmanii & $96 \mathrm{~h}$ & 10.78 & 8.92 & 1.5 & 2 \\
\hline & & & 13.03 & & \\
\hline L. aeneus & $96 \mathrm{~h}$ & 0.93 & 1.08 & $<1$ & 1 \\
\hline & & & 0.80 & & \\
\hline
\end{tabular}

${ }^{*}$ No confidence levels could be calculated.

The ionic gold acute toxicity data from both published literature and this study (Table 5) were used to generate respective SSD toxicity plots (Figures 11 and 12). The HC5 based on the combined data sets (literature and this study) for nAu and ionic gold was $42.78 \mathrm{mg} / \mathrm{L}$ and $2.44 \mathrm{mg} / \mathrm{L}$, respectively. The HC5 of the published literature was $4.46 \mathrm{mg} / \mathrm{L}$, whilst the indigenous species were more sensitive with an HC5 of 1.83.

\section{Discussion}

4.1. Characterization of $n A u$. Nanoparticle ecotoxicity involves several factors to consider, the initial size of the particles, the capping agent, how particles aggregate in an aquatic medium, and the charge that exists. All these affect the toxicity and ability for particle uptake in organisms [3, 47, $48]$. The changes in zeta potential and aggregation could be related to changes in conductivity and $\mathrm{pH}$ over time $[49,50]$. These changes in ionic strength based on the physicochemical water parameters allow for more binding sites on the particle surface due to an increased negative charge [51]. Therefore negative zeta potentials have the potential for aggregation to decrease. There is an increase in aggregation as the zeta potential becomes more positive as seen at $30 \mathrm{mg} / \mathrm{L}$ and above $[52,53]$.

When there is a change in any of these factors the behaviour of the $\mathrm{nAu}$ in an aquatic medium would also change. In Daphnia medium, there is uniform distribution of particle characteristics over the entire concentration range, while for fish medium there is a wide range of charges and size distributions which would affect particle uptake. Between $20 \mathrm{mg} / \mathrm{L}$ and $25 \mathrm{mg} / \mathrm{L}$ in the fish medium there was a diverse size distribution as $\mathrm{nAu}$ ranged from $17 \mathrm{~nm}$ to $890 \mathrm{~nm}$ and were present in equal intensities. The charge was negative at these concentrations and this could be adding to the smaller particles present because negative charges would cause aggregates to repel one another [52]. After $30 \mathrm{mg} / \mathrm{L}$ 
TABLE 5: Acute toxicity data from the published literature that were included used to derive the SSDs.

\begin{tabular}{|c|c|c|c|c|}
\hline Test species & Endpoint & Duration (h) & $\begin{array}{c}\mathrm{LC} 50 \\
\mathrm{HAuCl}_{4}(\mathrm{mg} / \mathrm{L}) \\
\end{array}$ & Reference \\
\hline \multicolumn{5}{|c|}{ Arthropods } \\
\hline D. magna & LC50 & 48 & 2 & Li et al. [40] \\
\hline D. magna & LC50 & 48 & 0.64 & Nam et al. [41] \\
\hline D. magna & LC50 & 48 & 0.15 & This study \\
\hline D. pulex & LC50 & 48 & 0.01 & This study \\
\hline M. macrocopa & LC50 & 48 & 0.62 & Nam et al. [40] \\
\hline \multicolumn{5}{|c|}{ Fish } \\
\hline D. rerio & LC50 & 96 & 4.85 & This study \\
\hline P. reticulata & LC50 & 96 & 20.58 & This study \\
\hline T. sparrmanii & LC50 & 96 & 10.78 & This study \\
\hline P. philander & LC50 & 96 & 7.53 & This study \\
\hline O. mossambicus & LC50 & 96 & 11.3 & This study \\
\hline L. aeneus & LC50 & 96 & 0.93 & This study \\
\hline T. arcticus & LC50 & 96 & 14.4 & Nam et al. [41] \\
\hline O. mykiss & LC50 & 96 & 10.7 & Nam et al. [41] \\
\hline O. kisutch & LC50 & 96 & 14.1 & Nam et al. [41] \\
\hline
\end{tabular}

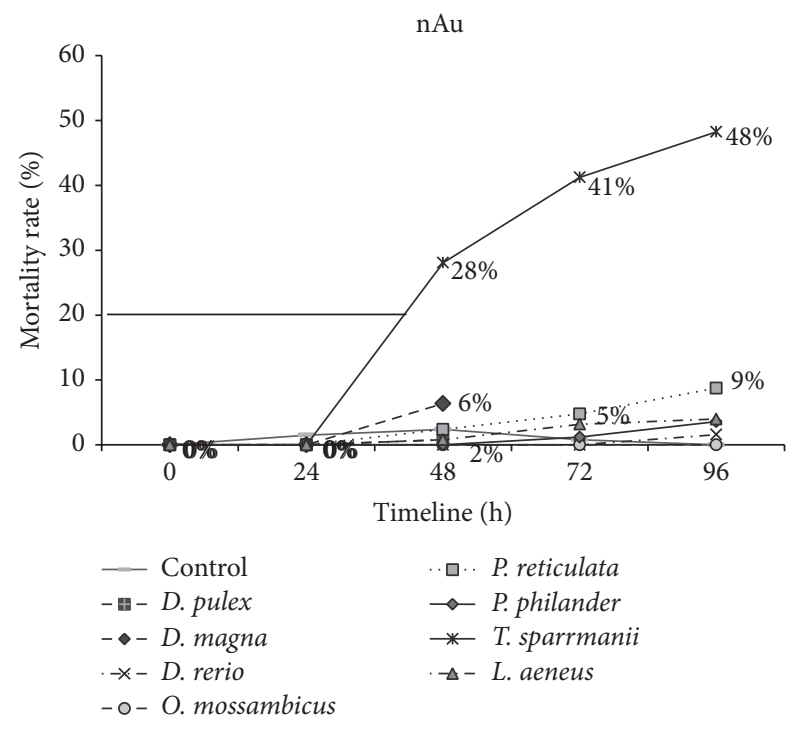

FIGURE 8: Cumulative mortalities of test organisms exposed to $\mathrm{nAu}$ over $48 \mathrm{~h}$ (daphnids) and $96 \mathrm{~h}$ (fish).

the $\mathrm{nAu}$ start forming large agglomerates, which, when observed under the TEM to reveal skeletal-like structures, may already be too large to be taken up by an organism [54-56]. Therefore there is a high enough concentration of $\mathrm{nAu}$ present for the aggregation to outweigh the charge and this would result in the nAu binding to one another and less are left in solution. However at $40 \mathrm{mg} / \mathrm{L}$ and $45 \mathrm{mg} / \mathrm{L}$ the agglomerates become so large that they are visible to the naked eye (up to $3 \mathrm{~mm}$ ) and therefore when a drop is collected for TEM only those particles which have been unable to bind to the larger agglomerate are visible. This would also explain why after $96 \mathrm{~h}$ it becomes increasingly difficult using TEM to

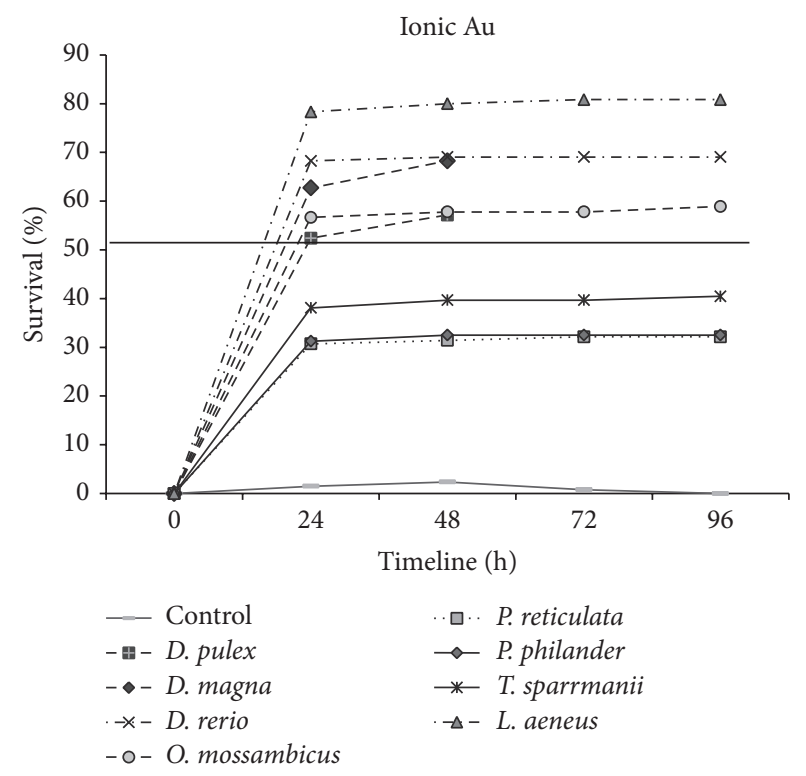

FIGURE 9: Cumulative mortalities of test organisms exposed to ionic gold over $48 \mathrm{~h}$ (daphnids) and $96 \mathrm{~h}$ (fish).

observe $\mathrm{nAu}$ in concentrations above $10 \mathrm{mg} / \mathrm{L}$ as they have already started to sediment out of solution.

As all citrate capped gold nanoparticles in the stock solution were around the $14 \mathrm{~nm}$ range it is evident that from the moment the particles were diluted in the respective environmental media they started to agglomerate to one another. This could also reflect the $10 \mathrm{mg} / \mathrm{L}$ loss of nanoparticle concentrations measured due to aggregations as the entire sample was not read but only a portion of it. The citrate capping is soluble and by the hydrolysis of 


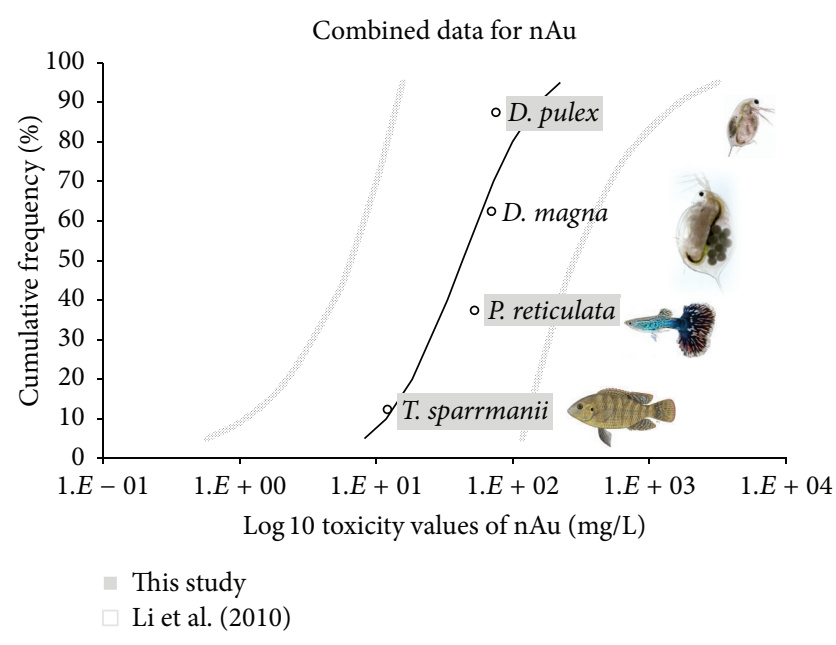

FIGURE 10: Species sensitivity distributions and confidence limits for $\mathrm{nAu}$ based on combined data from this study and the published literature.

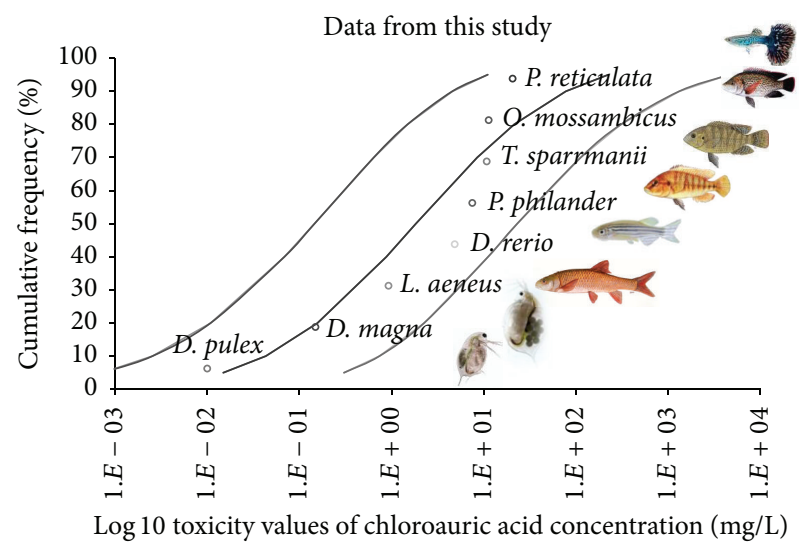

FIGURE 11: Species sensitivity distributions and confidence limits for ionic gold based on acute toxicity data from this study.

water is converted to citric acid [57]. Sections of the sodium citrate capping agent $\left(\mathrm{Na}_{3} \mathrm{C}_{6} \mathrm{H}_{5} \mathrm{O}_{7}\right)$ are washed off in the medium and particles become functionalized and therefore gain a charge [1] which allows them to stick to one another through van der Waals forces [47]. Divalent cations such as $\mathrm{Ca}^{2+}$ and $\mathrm{Mg}^{2+}$, which are present in the reconstituted OECD medium, effectively neutralize the surface charge of citrate coated $\mathrm{nAu}$, thereby compressing the electric double layer (repulsive forces) and enhancing aggregation $[58,59]$. This suggests that aggregates of nAu should be regulated by the type and concentration of the solvent and ionic strengths of reconstituted water medium [54, 60-62]. The zeta sizer indicated three peaks where the distribution of each size is represented as a percentage. It was found that to gain a better understanding of the particle behaviour at each concentration these percentages need to be taken into account.

Functional groups present on the nAu surface play a role in tissue distribution $[63,64]$. When additional ligands are

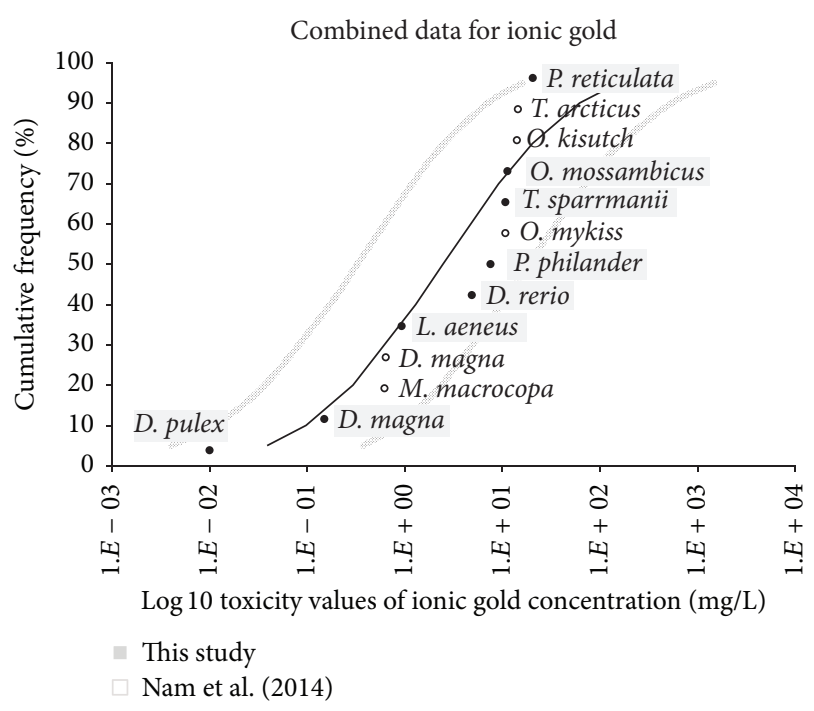

FIGURE 12: Species sensitivity distributions and confidence limits for ionic gold based on toxicity data from this study and the published literature [41].

not present as is the case with a controlled bioassay, the most stable form in solution for the nAu would be the hydrolyzed species, namely, functionalized to $\mathrm{AuOH}\left(\mathrm{H}_{2} \mathrm{O}\right)^{0}$ [65]. The $\mathrm{OH}$ frequency indicates that $\mathrm{OH}$ forms strong $\mathrm{H}$-bonding with groups of citrate caps present on $\mathrm{nAu}$ [66]. However depending on the $\mathrm{pH}$ and presence of chloride species this could change, where a $\mathrm{pH}$ of less than 4 would cause $\mathrm{AuCl}_{2}$ to form. However the neutral $\mathrm{pH}$ during these bioassays and FTIR results confirmed that this was not the case. When negative charges are present, as seen in $20 \mathrm{mg} / \mathrm{L}, 25 \mathrm{mg} / \mathrm{L}$, $40 \mathrm{mg} / \mathrm{L}$, and $45 \mathrm{mg} / \mathrm{L}$, this may change the toxicity of the particle where at a $\mathrm{pH}$ above 6 the predominant charge in solution would be $\mathrm{AuCl}(\mathrm{OH})_{3}{ }^{-}$. In cases where the $\mathrm{pH}$ was above 9 the functionality could change to $\mathrm{Au}(\mathrm{OH})_{4}^{-}$. Since the $\mathrm{pH}$ had a maximum of 8.7 for the duration of the experiment it can be concluded that negative charges were due to the presence of $\mathrm{AuCl}(\mathrm{OH})_{3}{ }^{-}$ions $[61,65,67]$. The cellular uptake is highly dependent on the functional groups attached to the particle, as these would affect the charge and aggregation patterns [1].

4.2. Acute Toxicity and SSDs. The nAu SSD revealed that fish were more sensitive to $\mathrm{nAu}$ with an LC50 (when calculable) of between $12.08 \mathrm{mg} / \mathrm{L}$ and $52.6 \mathrm{mg} / \mathrm{L}$, while daphnids were less sensitive with an LC50 ranging from approximately $70 \mathrm{mg} / \mathrm{L}$ to $75.31 \mathrm{mg} / \mathrm{L}$. Since arthropods are able to undergo molting they would be able to cope with the nAu particles adhered onto their carapace. Literature to date shows no evidence of nAu uptake in daphnids while gold ions would be taken up [40]. Fish species are unable to molt and since respiration takes place over the gill surface it provides a large surface area for $\mathrm{nAu}$ uptake within the nanometer range; therefore larger agglomerates could possibly be taken up [35]. Fish have a far more complex digestive, respiratory, and excretory system when compared to Daphnia since ionic gold ions 
have evolved with organisms and nAu have not; the fish is unable to cope with increased uptake and reduced excretion. Surface area and particle uptake play an important role in toxicity; it is therefore proposed that a threshold value for exposure concentrations exists; this occurs between $20 \mathrm{mg} / \mathrm{L}$ and $25 \mathrm{mg} / \mathrm{L}$ in the fish medium. Based on particle size distributions particle uptake is possible and accumulates in the organism in high enough concentrations to have an effect. The $\mathrm{nAu}$ have a high enough concentration to have an effect in an organism but agglomerations are still small enough in the medium to move through the cellular membrane. At concentrations above $25 \mathrm{mg} / \mathrm{L}$ particle interactions in the medium increase which decreases particle uptake into the organism.

When comparing the SSD plots it becomes apparent that the $\mathrm{nAu}$ and ionic gold have different distributions in toxicity. Smaller organisms, like Daphnia, have a higher sensitivity to ionic gold when compared to fish while for nAu exposures the opposite trend is seen. Reasons for this could be attributed to different effect and uptake mechanisms. Ionic gold follows the dose dependent response while $\mathrm{nAu}$ follow an aggregation theory response.

The SSD plots for the $\mathrm{nAu}$ and the ionic gold clearly indicate that there was a difference in the hazard potential of the two substances with the latter being an order of magnitude more toxic. This is in contrast to studies where SSDs comparing nano metals (i.e., $\mathrm{CuO}, \mathrm{ZnO}, \mathrm{nAg}$, and $\mathrm{nAl}_{2} \mathrm{O}_{3}$ ) to their bulk metal (ionic) equivalents revealed that the hazard potentials were very similar [31, 32, 35, 40]. These authors attributed similar toxic potentials to the dissolution of the ionic metals from the particle, causing the particle toxicity to be similar to the bulk metal. However compared to nano metals that have the potential for metal ion dissolution, more inert nanoparticles such as $\mathrm{TiO}_{2}$ and carbon nanotubes are much less toxic [34]. The results for $\mathrm{nAu}$ from this study support these findings.

At this stage the toxicity and therefore hazard assessment of nanoparticles are still very much based on dose-response (i.e., exposure concentration) relationships. Only when more data becomes available on the relationship between nanoparticle characteristics (e.g., size, shape, charge, and functional group) and the exposure medium will predictors of toxicity other than the release of metal ions become apparent. Notwithstanding the limitations of using only concentrationbased toxicity data, the information provided by the SSDs for nAu provides useful ecotoxicological comparisons with other nanomaterials.

\section{Conflict of Interests}

The authors declare that there is no conflict of interests regarding the publication of this paper.

\section{Acknowledgments}

The research is based upon work supported by the Department of Science and Technology. The authors wish to thank MINTEK for supplying the nAu stock solutions.

\section{References}

[1] C. S. Yah, "The toxicity of gold nanoparticles in relation to their physiochemical properties," Biomedical Research, vol. 24, no. 3, pp. 400-413, 2013.

[2] M. Janowski, J. W. M. Bulte, and P. Walczak, "Personalized nanomedicine advancements for stem cell tracking," Advanced Drug Delivery Reviews, vol. 64, no. 13, pp. 1488-1507, 2012.

[3] F. K. Alanazi, A. A. Radwan, and I. A. Alsarra, "Biopharmaceutical applications of nanogold," Saudi Pharmaceutical Journal, vol. 18, no. 4, pp. 179-193, 2010.

[4] D. Fernandes, H. Carmo, M. Bastos, and S. Fraga, "Influence of surface coating on the toxicity of gold nanoparticles in Caco-2 cells," Toxicology Letters, vol. 196, p. S277, 2010.

[5] G. Voskerician, M. S. Shive, R. S. Shawgo et al., "Biocompatibility and biofouling of MEMS drug delivery devices," Biomaterials, vol. 24, no. 11, pp. 1959-1967, 2003.

[6] I. H. El-Sayed, X. Huang, and M. A. El-Sayed, "Surface plasmon resonance scattering and absorption of anti-EGFR antibody conjugated gold nanoparticles in cancer diagnostics: applications in oral cancer," Nano Letters, vol. 5, no. 5, pp. 829-834, 2005.

[7] S. Arora, J. M. Rajwade, and K. M. Paknikar, "Nanotoxicology and in vitro studies: the need of the hour," Toxicology and Applied Pharmacology, vol. 258, no. 2, pp. 151-165, 2012.

[8] H. J. Byrne, I. Lynch, W. H. de Jong et al., Protocols for Assessment of Biological Hazards of Engineered Nanomaterials, The European Network on the Health and Environmental Impact of Nanomaterials, 2010.

[9] G. C. Delgado, "Economics and governance of nanomaterials: potential and risks," Technology in Society, vol. 32, no. 2, pp. 137$144,2010$.

[10] N. Lewinski, V. Colvin, and R. Drezek, "Cytotoxicity of nanoparticles," Small, vol. 4, no. 1, pp. 26-49, 2008.

[11] D. Kühnel and C. Nickel, "The OECD expert meeting on ecotoxicology and environmental fate-towards the development of improved OECD guidelines for the testing of nanomaterials," Science of the Total Environment, vol. 472, pp. 347-353, 2014.

[12] V. Wepener and P. M. Chapman, "South African ecotoxicology: present status and future prognosis," African Journal of Aquatic Science, vol. 37, no. 3, pp. 229-234, 2012.

[13] J. C. Chapman, "The role of ecotoxicity testing in assessing water quality," Australian Journal of Ecology, vol. 20, no. 1, pp. 20-27, 1995.

[14] K. D. Kimball and S. A. Levin, "Limitations of laboratory bioassays: the need for ecosystem-level testing," BioScience, vol. 35, no. 3, pp. 165-171, 1985.

[15] J. Martins, L. O. Teles, and V. Vasconcelos, "Assays with Daphnia magna and Danio rerio as alert systems in aquatic toxicology," Environment International, vol. 33, no. 3, pp. 414-425, 2007.

[16] D. R. Grothe, K. L. Dickson, and D. K. Reed-Judkins, Whole Effluent Toxicity Testing: An Evaluation of Methods and Prediction of Receiving System Impacts, SETAC Special Publications Series, SETAC Press, Pensacola, Fla, USA, 1996.

[17] G. M. Rand, P. G. Wells, and L. S. McCarty, Fundamentals of Aquatic Toxicology: Effects, Environmental Fate and Risk Assessment, edited by: G. M. Rand, Taylor \& Francis, 2nd edition, 1995.

[18] P. B. Dorn, "An industrial perspective on whole effluent toxicity testing," in Whole Effluent Toxicity Testing: An Evaluation of Methods and Predictions of Receiving Impacts, D. R. Grothe, 
K. L. Dickson, and D. K. Reed-Judkins, Eds., Society of Environmental Toxicology and Chemistry Special Publications Series, Society of Environmental Toxicology and Chemistry, Pensacola, Fla, USA, 1996.

[19] H. C. Sarakinos, N. Bermingham, P. A. White, and J. B. Rasmussen, "Correspondence between whole effluent toxicity and the presence of priority substances in complex industrial effluents," Environmental Toxicology and Chemistry, vol. 19, no. 1, pp. 63-71, 2000.

[20] R. Smolders, L. Bervoets, V. Wepener, and R. Blust, "A conceptual framework for using mussels as biomonitors in whole effluent toxicity," Human and Ecological Risk Assessment, vol. 9, no. 3, pp. 741-760, 2003.

[21] S. Jergentz, P. Pessacq, H. Mugni, C. Bonetto, and R. Schulz, "Linking in situ bioassays and population dynamics of macroinvertebrates to assess agricultural contamination in streams of the Argentine pampa," Ecotoxicology and Environmental Safety, vol. 59, no. 2, pp. 133-141, 2004.

[22] P. M. Chapman, "Whole effluent toxicity testing-usefulness, level of protection, and risk assessment," Environmental Toxicology and Chemistry, vol. 19, no. 1, pp. 3-13, 2000.

[23] Department of Water Affair and Forestry (DWAF), "The management of complex industrial wastewater discharges: introducing the Direct Estimation of Ecological Effect Potential (DEEEP) approach," A Discussion Document, Department of Water Affairs and Forestry, Institute for Water Quality Studies, Pretoria, South Africa, 2003.

[24] A. R. Fernández-Alba, L. H. Guil, G. D. López, and Y. Chisti, "Toxicity of pesticides in wastewater: a comparative assessment of rapid bioassays," Analytica Chimica Acta, vol. 426, no. 2, pp. 289-301, 2001.

[25] C. G. Palmer, W. J. Muller, and H. D. Davies-Coleman, "Applied aquatic toxicology: sub-lethal methods, whole effluent testing and communication," WRC Report No. 1245/1/04, Water Research Commission, Pretoria, South Africa, 2004.

[26] L. Maltby, N. Blake, T. C. M. Brock, and P. J. van den Brink, "Insecticide species sensitivity distributions: importance of test species selection and relevance to aquatic ecosystems," Environmental Toxicology and Chemistry, vol. 24, no. 2, pp. 379388, 2005.

[27] L. Posthuma, T. P. Traas, and G. W. Suter II, "General introduction to species sensitivity distributions", in Species Sensitivity Distribution in Ecotoxicology, L. Posthuma, T. P. Traas, and G. W. Suter II, Eds., Lewis Publishers, Boca Raton, Fla, USA, 2002.

[28] J. R. Wheeled, E. P. M. Grist, K. M. Y. Leung, D. Morritt, and M. Crane, "Species sensitivity distributions: data and model choice," Marine Pollution Bulletin, vol. 45, no. 1-12, pp. 192-202, 2002.

[29] M. C. Newman, D. R. Ownby, L. C. A. Mezin et al., "Applying species-sensitivity distribustion in ecoogical risk assessment: assumptions of distribution type and sufficient numbers of species," Environmental Toxicology and Chemistry, vol. 19, no. 2, pp. 508-515, 2000.

[30] S. Browne, The role of acute toxicity data for South African freshwater macroinvertebrates in the derivation of water quality guidelines for salinity [M.S. thesis], Rhodes University, Grahamstown, South Africa, 2005.

[31] N. Adam, C. Schmitt, L. de Bruyn, D. Knapen, and R. Blust, "Aquatic acute species sensitivity distributions of $\mathrm{ZnO}$ and $\mathrm{CuO}$ nanoparticles," Science of The Total Environment, vol. 526, pp. 233-242, 2015.
[32] K. L. Garner, S. Suh, H. S. Lenihan, and A. A. Keller, "Species sensitivity distributions for engineered nanomaterials," Environmental Science \& Technology, vol. 49, no. 9, pp. 5753-5759, 2015.

[33] H. Johnston, D. Brown, A. Kermanizadeh, E. Gubbins, and V. Stone, "Investigating the relationship between nanomaterial hazard and physicochemical properties: informing the exploitation of nanomaterials within therapeutic and diagnostic applications," Journal of Controlled Release, vol. 164, no. 3, pp. 307-313, 2012.

[34] B. J. Shaw and R. D. Handy, "Physiological effects of nanoparticles on fish: a comparison of nanometals versus metal ions," Environment International, vol. 37, no. 6, pp. 1083-1097, 2011.

[35] S. J. Klaine, P. J. J. Alvarez, G. E. Batley et al., "Nanomaterials in the environment: behavior, fate, bioavailability, and effects," Environmental Toxicology and Chemistry, vol. 27, no. 9, pp. 1825$1851,2008$.

[36] C. J. Murphy, A. M. Gole, J. W. Stone et al., "Gold nanoparticles in biology: beyond toxicity to cellular imaging," Accounts of Chemical Research, vol. 41, no. 12, pp. 1721-1730, 2008.

[37] G. Fren, "Preparation of gold dispersions of varying particle size: controlled nucleation for the regulation of the particle size in monodisperse gold suspensions," Nature Physics, vol. 241, pp. 20-22, 1973.

[38] OECD, Oecd Guideline for Testing of Chemicals: Fish, Acute Toxicity Tests, 1992.

[39] E. Truter, Method of Estimating the Chronic Toxicity of a Chemical or Water Sampleto the Cladoceran Daphnia pulex, Department of Water Affairs and Forestry, Department of Water Affairs \& Forestry, Pretoria, South Africa, 1994.

[40] T. Li, B. Albee, M. Alemayehu et al., "Comparative toxicity study of Ag, Au, and Ag-Au bimetallic nanoparticles on Daphnia magna," Analytical and Bioanalytical Chemistry, vol. 398, no. 2, pp. 689-700, 2010.

[41] S.-H. Nam, W.-M. Lee, Y.-J. Shin et al., "Derivation of guideline values for gold (III) ion toxicity limits to protect aquatic ecosystems," Water Research, vol. 48, no. 1, pp. 126-136, 2014.

[42] F. von der Kammer, P. L. Ferguson, P. A. Holden et al., "Analysis of engineered nanomaterials in complex matrices (environment and biota): general considerations and conceptual case studies," Environmental Toxicology and Chemistry, vol. 31, no. 1, pp. 3249, 2012.

[43] V. Stone, B. Nowack, A. Baun et al., "Nanomaterials for environmental studies: classification, reference material issues, and strategies for physico-chemical characterisation," Science of the Total Environment, vol. 408, no. 7, pp. 1745-1754, 2010.

[44] M. A. Hamilton, R. C. Russo, and R. V. Thurston, “Trimmed Spearman-Karber method for estimating median lethal concentrations in toxicity bioassays," Environmental Science \& Technology, vol. 11, no. 7, pp. 714-719, 1977, Correction: vol. 12, p. $417,1978$.

[45] American Public Health Association (APHA), Standard Methods for the Examination of Water and Wastewater, American Water Works Association (AWWA), Water Environment Federation (WEF), Washington, DC, USA, 1992.

[46] United States Environmental Protection Agency (USEPA), CADDIS Volume 4: Data Analysis, United States Environmental Protection Agency (USEPA), 2012, http://www.epa.gov/.

[47] N. Oh and J.-H. Park, "Endocytosis and exocytosis of nanoparticles in mammalian cells," International Journal of Nanomedicine, vol. 9, no. 1, pp. 51-63, 2014. 
[48] K. T. Kim, S. J. Klaine, J. Cho, S.-H. Kim, and S. D. Kim, "Oxidative stress responses of Daphnia magna exposed to $\mathrm{TiO}_{2}$ nanoparticles according to size fraction," Science of the Total Environment, vol. 408, no. 10, pp. 2268-2272, 2010.

[49] B. Fadeel and A. E. Garcia-Bennett, "Better safe than sorry: understanding the toxicological properties of inorganic nanoparticles manufactured for biomedical applications," Advanced Drug Delivery Reviews, vol. 62, no. 3, pp. 362-374, 2010.

[50] A. M. Schrand, M. F. Rahman, S. M. Hussain, J. J. Schlager, D. A. Smith, and A. F. Syed, "Metal-based nanoparticles and their toxicity assessment," Wiley Interdisciplinary Reviews: Nanomedicine and Nanobiotechnology, vol. 2, no. 5, pp. 544568,2010

[51] W. Cui, J. Li, Y. Zhang, H. Rong, W. Lu, and L. Jiang, "Effects of aggregation and the surface properties of gold nanoparticles on cytotoxicity and cell growth," Nanomedicine: NBM, vol. 8, no. 1, pp. 46-53, 2011.

[52] H. Weinberg, A. Galyean, and M. Leopold, "Evaluating engineered nanoparticles in natural waters," TrAC Trends in Analytical Chemistry, vol. 30, no. 1, pp. 72-83, 2011.

[53] R. J. Griffitt, J. Luo, J. Gao, J.-C. Bonzongo, and D. S. Barber, "Effects of particle composition and species on toxicity of metallic nanomaterials in aquatic organisms," Environmental Toxicology and Chemistry, vol. 27, no. 9, pp. 1972-1978, 2008.

[54] A. Elsaesser and C. V. Howard, "Toxicology of nanoparticles," Advanced Drug Delivery Reviews, vol. 64, no. 2, pp. 129-137, 2012.

[55] R. N. Grass, L. K. Limbach, E. K. Athanassiou, and W. J. Stark, "Exposure of aerosols and nanoparticle dispersions to in vitro cell cultures: a review on the dose relevance of size, mass, surface and concentration," Journal of Aerosol Science, vol. 41, no. 12, pp. 1123-1142, 2010.

[56] L. Treuel, M. Malissek, J. S. Gebauer, and R. Zellner, "The influence of surface composition of nanoparticles on their interactions with serum albumin," ChemPhysChem, vol. 11, no. 14, pp. 3093-3099, 2010.

[57] A. Tabrizi, F. Ayhan, and H. Ayhan, "Gold nanopartice synthesis and characterisation," Hacettepe Journal of Biology and Chemistry, vol. 37, no. 3, pp. 217-226, 2009.

[58] M. Baalousha, Y. Nur, I. Römer, M. Tejamaya, and J. R. Lead, "Effect of monovalent and divalent cations, anions and fulvic acid on aggregation of citrate-coated silver nanoparticles," Science of the Total Environment, vol. 454-455, pp. 119-131, 2013.

[59] M. Delay, T. Dolt, A. Woellhaf, R. Sembritzki, and F. H. Frimmel, "Interactions and stability of silver nanoparticles in the aqueous phase: influence of natural organic matter (NOM) and ionic strength," Journal of Chromatography A, vol. 1218, no. 27, pp. 4206-4212, 2011.

[60] I. Römer, T. A. White, M. Baalousha, K. Chipman, M. R. Viant, and J. R. Lead, "Aggregation and dispersion of silver nanoparticles in exposure media for aquatic toxicity tests," Journal of Chromatography A, vol. 1218, no. 27, pp. 4226-4233, 2011.

[61] J. Farkas, P. Christian, J. A. G. Urrea et al., "Effects of silver and gold nanoparticles on rainbow trout (Oncorhynchus mykiss) hepatocytes," Aquatic Toxicology, vol. 96, no. 1, pp. 44-52, 2010.

[62] D. G. Abradelo, R. Cao, and R. Cea, "Self-aggregation of bilayer ferrocenyl termini gold nanoparticles," Inorganic Chemistry Communications, vol. 10, no. 5, pp. 511-513, 2007.

[63] G. M. Fent, S. W. Casteel, D. Y. Kim, R. Kannan, K. Katti, and N. Chanda, "Biodistribution of maltose and gum arabic hybrid gold nanoparticles after intravenous injection in juvenile swine," Nanomedicine: Nanotechnology, Biology, and Medicine, vol. 5, no. 2, pp. 128-135, 2009.

[64] Y.-J. Gu, J. Cheng, C.-C. Lin, Y. W. Lam, S. H. Cheng, and W.T. Wong, "Nuclear penetration of surface functionalized gold nanoparticles," Toxicology and Applied Pharmacology, vol. 237, no. 2, pp. 196-204, 2009.

[65] B. H. Stuart, Modern Infrared Spectroscopy, Analytical Chemistry by Open Learning Series, John Wiley \& Sons, 1995.

[66] R. Pal, S. Panigrahi, D. Bhattacharyya, and A. S. Chakraborti, "Characterization of citrate capped gold nanoparticle-quercetin complex: experimental and quantum chemical approach," Journal of Molecular Structure, vol. 1046, pp. 153-163, 2013.

[67] A. Lapresta-Fernández, A. Fernández, and J. Blasco, "Nanoecotoxicity effects of engineered silver and gold nanoparticles in aquatic organisms," Trends in Analytical Chemistry, vol. 32, pp. 40-59, 2012. 

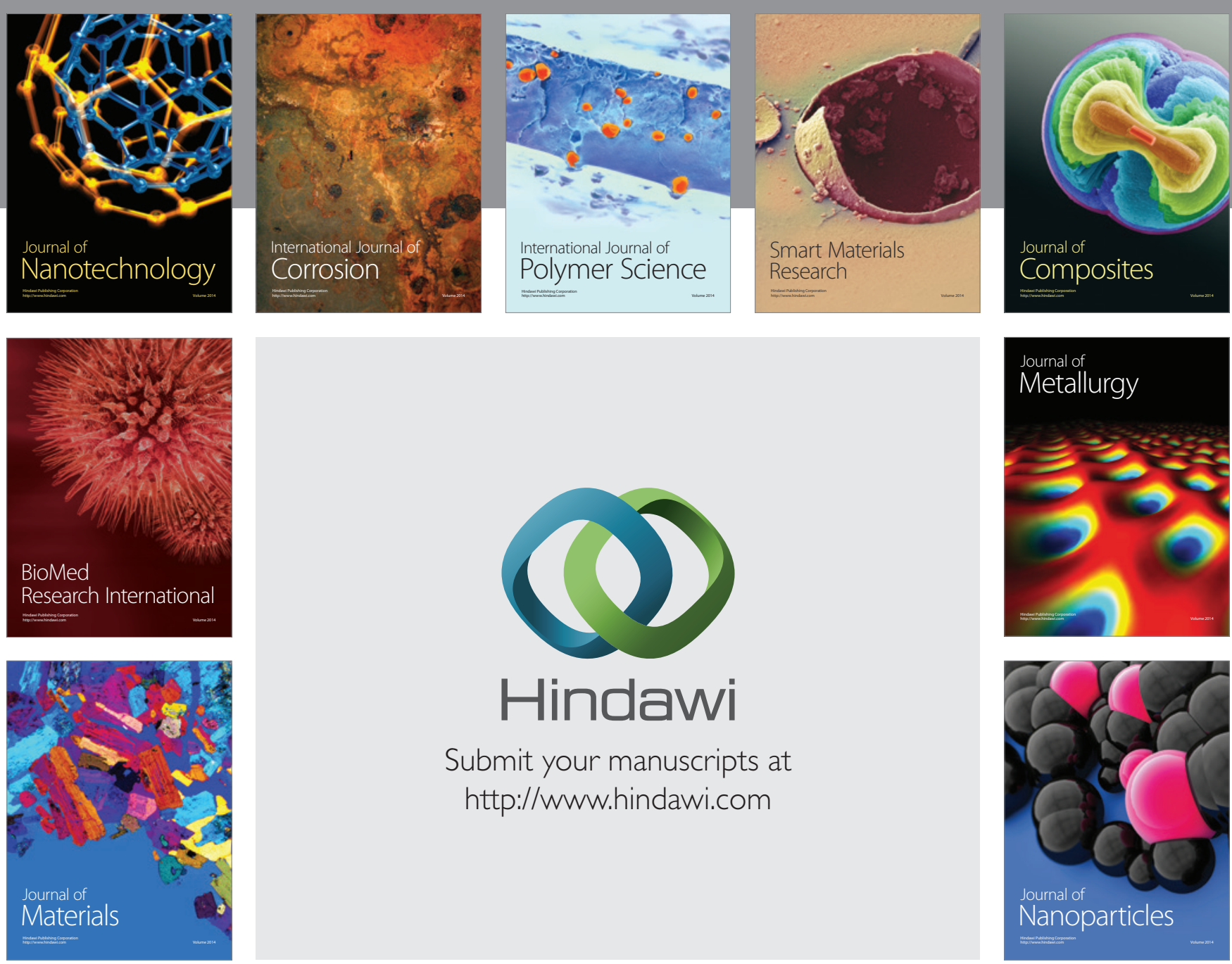

Submit your manuscripts at http://www.hindawi.com
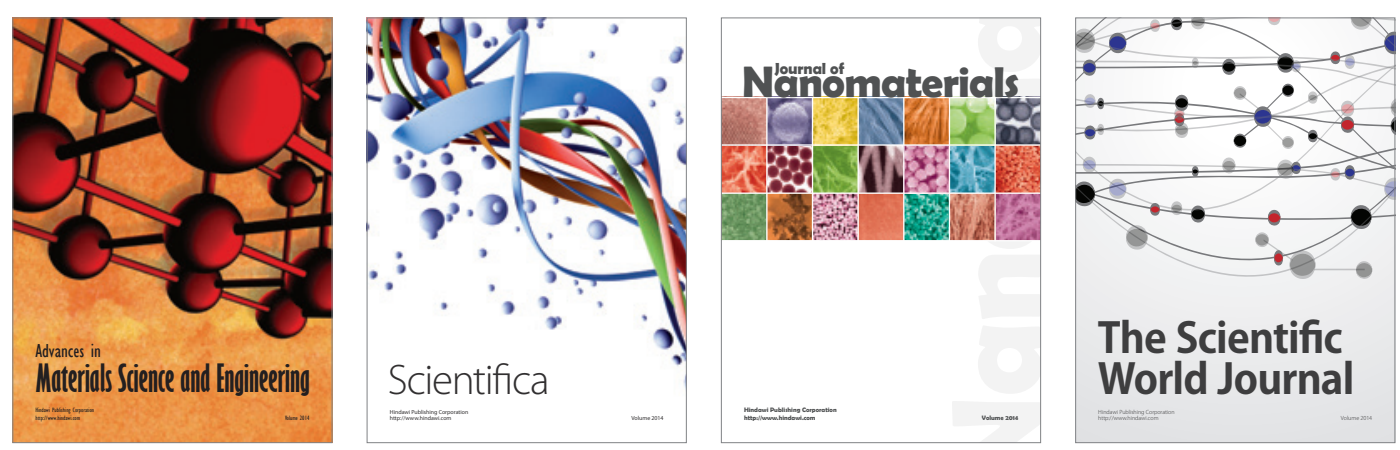

\section{The Scientific World Journal}
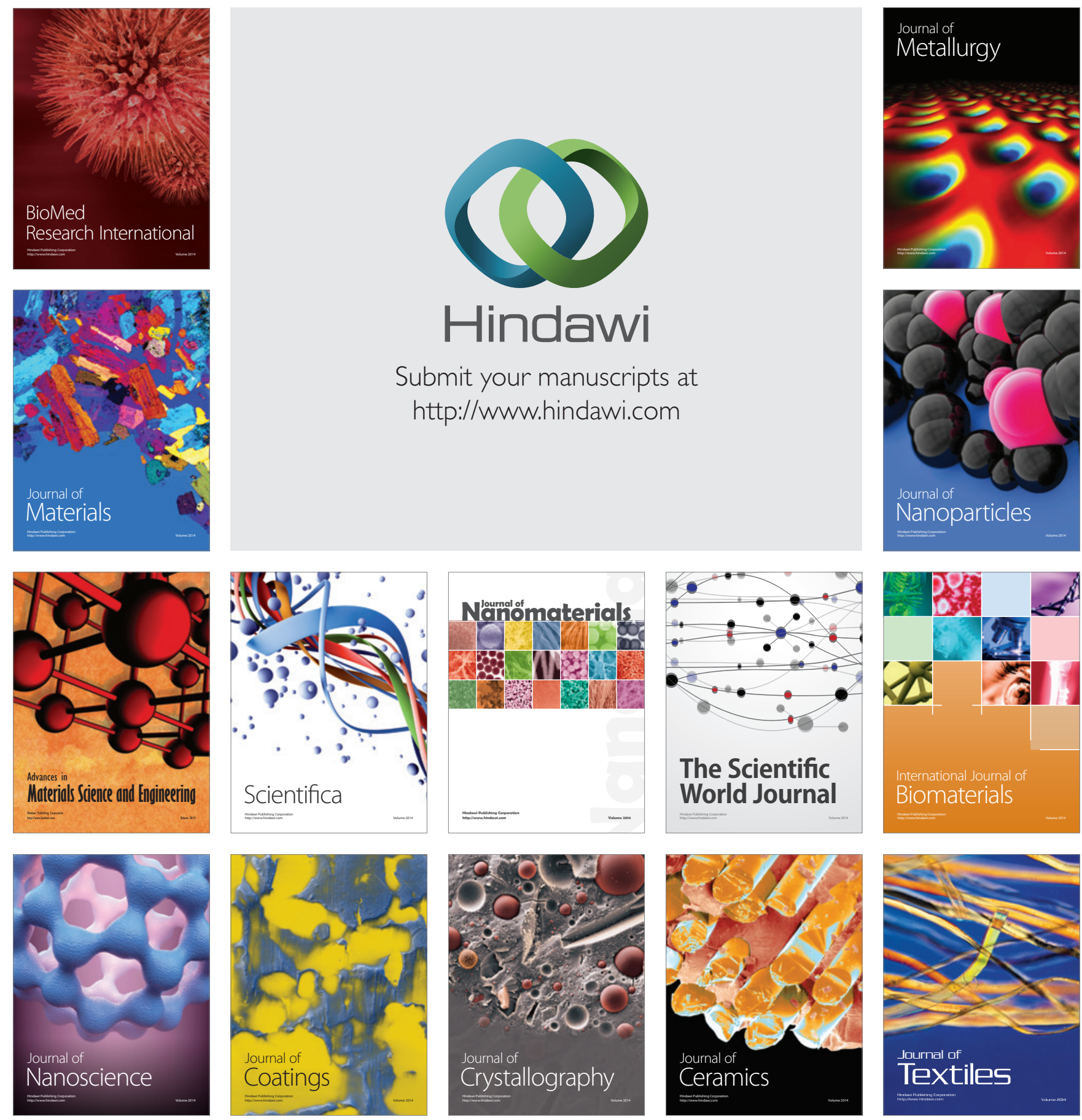